Archaeologia Historica Polona tom 26, 2018, ISSN 1425-3534

Państwowy Instytut Geologiczny

http://dx.doi.org/10.12775/AHP.2018.007

Państwowy Instytut Badawczy

Akme - Zdzisław Wiśniewski, Sp. z o.o.

JANUSZ BADURA, TOMASZ A. KASTEK

\title{
Topograficzne uwarunkowania lokalizacji zamków wrocławskich
}

\section{Topographical conditions of the location of Wroclaw castles}

Zarys treści. W artykule przedstawione zostały zamki wrocławskie na tle przemian związanych z przeobrażeniami biegu Odry w średniowieczu. W krótki sposób zaprezentowano historię trzech obiektów: na Ostrowie Tumskim, lewobrzeżnego (później cesarskiego) oraz drugiego lewobrzeżnego (późniejszy Arsenał Miejski, który nie został ukończony), na tle powstającego w XIII wieku miasta lokacyjnego. Na tak zagospodarowywany teren wpływ miały zmiany przebiegu głównego koryta Odry oraz sztuczne utrzymywanie lub przekopywanie kanałów. Procesy naturalne i antropogeniczne doprowadziły do zmiany charakteru rzeki z meandrującej poza obszarem miastem, na anastozomującą na obszarze średniowiecznego Wrocławia.

Stowa kluczowe: Wrocław, średniowiecze, Odra, topografia przedlokacyjnego miasta, zamki piastowskie.

Ostanie dwudziestolecie badań archeologiczno-architektonicznych pozwoliło ponownie przyjrzeć się początkom Wrocławia i zamkom istniejącym w jego obrębie. Liczne inwestycje na tym terenie przyniosły potężną ilość materiału archeologiczno-architektonicznego, dzięki któremu możemy ponownie przeanalizować teorie związane z początkami grodu i miasta. Współpraca interdyscyplinarna pozwala wyciągać nowe wnioski z badań porównawczych, między innymi geologicznych i georadarowych. Dzięki analizie archiwów i wyników badań terenowych można było ponownie spojrzeć na zagospodarowywanie Odry, jej wysp oraz terenów do niej przylegających - nadbrzeżnych. Analiza powierzchni niezmienionych antropogenicznie, poczyniona przez Janusza Badurę (2010), pozwoliła zwrócić uwagę na powody umiejscawiania wrocławskich zamków, zwłaszcza lewobrzeżnych, w ich kontekście historycznym. 
Książę zagospodarowując tereny pod przyszłe osadnictwo grodowe czy miejskie, musiał uregulować bieg głównych rzek, tj. Odry i Oławy, które miały wielki wpływ na to osadnictwo. Tu się zaczynał problem związany z istnieniem wrocławskiego ośrodka grodowego i miejskiego. Już założenie grodu wiązało się $\mathrm{z}$ dużą inwestycją, jaką było utworzenie miejsca pod przyszłą siedzibę grodową z większej piaszczystej wyspy znajdującej się w ramionach Odry Szczytnickiej. Ponadto należało zabezpieczyć przyszłe osadnictwo, budując potężne wały grodowe, o czym wspomina dokument z 1172 roku (Bukowski 1979, s. 13). Inaczej przedstawiała się sytuacja z zamkami lewobrzeżnymi, których usytuowanie związane było z rzeźbą terenu, ale i z układem miejskiej zabudowy. Żeby to zrozumieć trzeba spojrzeć na przekształcanie biegu Odry na obszarze ówczesnego Wrocławia, zarówno w wyniku naturalnej migracji koryta Odry, jak i w celowej działalności mieszkańców.

Odtworzenie przedlokacyjnego ukształtowania średniowiecznego Wrocławia w latach 900-1200 AD jest istotne dla zrozumienia ówczesnych wyborów miejsc lokacji ważnych obiektów. Późniejsze przekształcenia terenu, zarówno następujące $\mathrm{w}$ wyniku nawarstwień kulturowych, jak i naturalnych procesów, głównie związanych z działalnością Odry, zatarły pierwotne ukształtowanie powierzchni. Należy jednak mieć świadomość, że odtwarzanie dawnego krajobrazu jest tylko przybliżeniem opierającym się na analizie materiałów o różnej skali dokładności, obarczonej jednak subiektywną oceną materiałów oraz możliwościami własnych obserwacji osadów w wykopach budowlanych lub badawczych, w tym archeologicznych. Nie zawsze możliwe jest prawidłowe interpretowanie archiwalnych profili, otworów wiertniczych oraz opisów w dokumentacjach archeologicznych enigmatycznie opisujących naturalne podłoże jako calec. W celu odtworzenia kopalnej powierzchni średniowiecznego Wrocławia posłużono się kilkoma metodami. Oparto się na osobiście przeprowadzonych obserwacjach licznych wkopów inwestycyjnych lub archeologicznych prowadzonych na tym obszarze. Obserwacje te pozwoliły na interpretację około 7500 profili otworów geologiczno-inżynierskich oraz hydrogeologicznych wykonanych w rejonie obecnego Śródmieścia i na obszarze Starego Miasta. Kolejnym ważnym źródłem informacji były stare mapy i plany miasta oraz rekonstrukcje już nieistniejących koryt rzecznych (Leonhardt 1901). Na ich podstawie wytyczono biegi koryt Odry, a także możliwe było odkrycie meandra koło kościoła pw. św. Mikołaja i Bramy Mikołajskiej. Analizowano, niestety, tylko ogólnie dostępne w publikacjach dane dotyczące prac hydrotechnicznych, czasów najstarszych lokacji mostów i młynów oraz awulsji Odry po powodziach. Na ich podstawie opracowano cyfrowy obraz powierzchni terenu oraz hipotezę powstania wysp wrocławskich.

Dolina Odry, taka jaką znamy, powstawała stopniowo od czasu zaniku ostatniego lądolodu na tym obszarze w zlodowaceniu Warty, czyli około 140 tys. lat temu. Na przedpolu stagnującego czoła lądolodu na Wzgórzach Trzebnickich, 
Dalkowskich oraz innych tworzących łuk wyginający się ku północnemu zachodowi utworzyła się Pradolina Wrocławsko-Magdebursko-Bremeńska (Badura i in. 2013). Równolegle do łuku czoła lądolodu i wzgórz na ich przedpolu płynęła rzeka, zasilana głównie przez wody wypływające z topniejącego lądolodu. Dalsze jego wycofywanie się zmieniło reżim rzeki; zasilały ją wody mające źródła w Karpatach, Sudetach oraz na Przedgórzu Sudeckim. Doliną tą rzeka płynęła aż do czasu geologicznej katastrofy, jaką było utworzenie w kolejnym zlodowaceniu Wisły kaptażu w wyniku, którego powstał przełom ścinawski przez Wzgórza Dalkowskie. Odra popłynęła do powstałej wówczas Pradoliny Barucko-Głogowskiej. Na śląskim odcinku doliny rzeka wcięła się w swoje osady; powstała terasa wznosząca się od 5 do $7 \mathrm{~m}$ nad jej poziom. Na powierzchni tej terasy założone zostało Stare Miasto we Wrocławiu (ryc. 1).

W późniejszym okresie, pod koniec zlodowacenia Wisły, powstała kolejna terasa, która zachowała się we wschodniej części miasta. W czasie zlodowacenia Wisły Odra utworzyła szeroką, dochodzącą do $19 \mathrm{~km}$ dolinę (Badura, Burdukiewicz 2016, ryc. 10). Na powierzchni terasy, 5-7 m nad poziomem rzeki, prawdopodobnie zachowały się obniżenia o głębokości $0,5-1,0 \mathrm{~m}$, po roztokowym systemie koryt Odry (Badura 2010). Przypuszczalnie dolny odcinek jednego z tych koryt został wykorzystany jako zagłębienie, którym poprowadzono wykop zewnętrznej fosy miejskiej.

W holocenie lub jeszcze pod sam koniec zlodowacenia Wisły w ciepłym klimacie zmienił się charakter Odry. $Z$ roztopowej, czyli wieloramiennej, przekształciła się w rzekę meandrującą. Z analizy map oraz historycznych przekazów wiemy, że Odra często zmieniała bieg koryta w obrębie szerokiego dna doliny. Odtworzenie chronologii tych zmian bez badań wieku osadów nie jest możliwe. Część z nich zapisana została w różnych dokumentach, ale zapewne część, jeśli nie większość tych danych czeka na odkrywców.

Problem charakteru systemu rzecznego Odry na obszarze średniowiecznego Wrocławia wynika z wyraźnej anomalii w przebiegu jej koryta w porównaniu do odcinków doliny położonych przed i za miastem. Zarówno po stronie wschodniej, jak i zachodniej, na wszystkich materiałach kartograficznych, zdjęciach lotniczych czy LiDAR-owych widoczne są szerokie łuki meandrowe. Tylko na obszarze staromiejskim o długości około $2,5 \mathrm{~km}$ w dolinie Odry występują wyspy, wskazujące, że z meandrującej stała się ona anastozomująca. Ten typ rzeki jest charakterystyczny między innymi dla obszarów tektoniczne aktywnych, gdy teren, przez który ona przepływa obniża się. Z analizy danych geologicznych wynika, że podłoże wykazuje tendencję do obniżania pod prawie całym Wrocławiem, a nie wyłącznie pod jego staromiejską częścią (Badura, Przybylski, Zuchiewicz 2004; Grzempowski i in. 2009). Dane geodezyjne wskazywały na szybkie osiadania części Wrocławia. Kolejne badania wykazały, że wcześniej obserwowane pionowe 


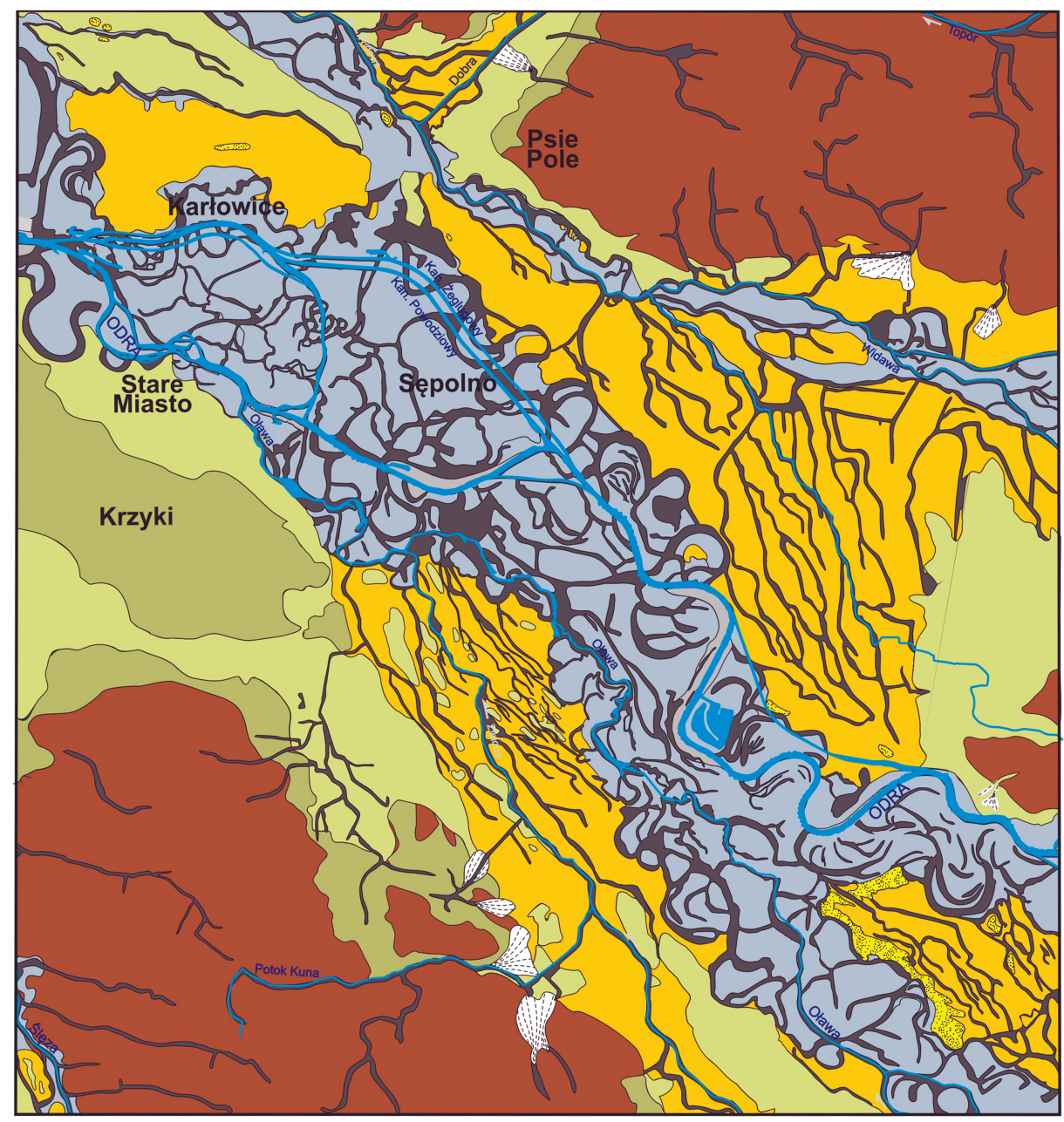

\section{2}

3

4

1.5.

6

7

9 雪

Ryc. 1. Koryta Odry odtworzone na podstawie map historycznych, topograficznych i geologicznych. 1 - wysoczyzna plejstoceńska zlodowacenie Odry; 2 - zlodowacenie Wisły: terasa $15-17 \mathrm{~m} \mathrm{n}$. p. Odry; 3 - terasa 5-7 m n.p. Odry; 4 - terasa 3-4 m n.p. Odry; 5 - wydmy, holocen; 6 - terasa $2-3$ m n.p. Odry; 7 - terasa 0,5 m n.p. Odry; 8 - fosylne koryta rzeczne; 9 - stożki napływowe (oprac. J. Badura)

Fig. 1. The Odra River beds reconstructed based on historical, topographical and geological maps. 1 - Pleistocene height the Riss Glaciation; 2 - the Vistulian Glaciation: terrace 15-17 $\mathrm{m}$ above the Odra River level; 3 - terrace 5-7 $\mathrm{m}$ above the Odra River level; 4 - terrace 3-4 m above the Odra River level; 5 - dunes, Holocene; 6 - terrace 2-3 $\mathrm{m}$ above above the Odra River level; 7 - terrace $0.5 \mathrm{~m}$ above the Odra River level; 8 - fossil riverbeds; 9 - alluvial fans (edited by J. Badura) 
przemieszczenia związane były z osiadaniem powierzchni terenu w wyniku nadmiernej eksploatacji wód podziemnych (Grzempowski i in. 2009).

Szczegółowa analiza historycznych opracowań kartograficznych oraz wyników prac archeologicznych wykazała, że na obszarze wcześniej uważanym za terasę o wysokości 5-7 m występują osady utworzone w wyniku holoceńskiego meandrowania Odry (Badura 2010). Powstałe po XIII wieku nawarstwienia kulturowe zamaskowały te obniżenia. I tak po wschodniej stronie Starego Miasta, na południe od zespołu klasztornego Bernardynów z profili wierceń geologiczno-inżynierskich można odtworzyć przebiegi pasm piaszczystych odsypów meandrowych i położonych między nimi osadów namułów mineralno-organicznych, a nawet torfów.

Kolejny łuk meandrowy Odry zinterpretowano pod Nowym Targiem. Potwierdziły się wcześniejsze interpretacje Andrzeja Traczyka o zaleganiu na tym obszarze młodych holoceńskich osadów (Traczyk 2005). Obecność w tym rejonie zakola meandrowego wyjaśnia dwa problemy: jeden to odkrycie w pobliżu ulicy Wita Stwosza pierwszej średniowiecznej ulicy o skośnym przebiegu w stosunku do późniejszego - kratowego układu ulic w tym rejonie (Kaźmierczyk 1965). Drugi to odbiegający od wzorca przebieg wschodniego odcinka ulicy Wita Stwosza. Obecnie można przyjąć, że lekki łuk ulicy związany był z zakolem meandru, a skośny bieg ulicy z trawersem drogi przecinającej około 1,5 m wysokości krawędź wyższej terasy.

Obniżenie z czytelną tylko zachodnią krawędzią meandra odsłonięto także na Placu Uniwersyteckim, na dziedzińcu między dawnym zamkiem książęcym a budynkiem Ossolineum. Pod utworami antropogenicznymi znajdowały się piaski ze szczątkami organicznymi oraz kostnymi, przykryte humusem bez materiałów ceramicznych. Obecność niewielkiego obniżenia meandrowego położonego po drugiej stronie Uniwersytetu wskazuje, że zamek książęcy usytuowany był na ostrodze meandrowej wzniesionej ponad dolinę. Takie położenie sprawiało, że z trzech stron był on dodatkowo chroniony. Obecność ostrogi meandrowej może też tłumaczyć lokalną nazwę terenu przylegającego do zamku - Wróble Wzgórze.

Kolejny meander widoczny jest na planie Barthela i Bartholomäusa Weinerów - pierwszym planie Wrocławia z 1562 roku (ryc. 2). W jego obrębie jeszcze w XVIII wieku istniało starorzecze. Przebieg meandra wyznaczają dawne ulice Rybacka oraz północna pierzeja Placu Jana Pawła II. Zakładając symetryczny w stosunku do fosy zarys łuku meandra po stronie wschodniej posadowienie Bramy Mikołajskiej oraz zamku wójtowskiego (Arsenału Miejskiego) pokazuje, że i te obiekty wzniesiono wykorzystując wyższe położenie topograficzne. Także znajdujący się już za murami miejskimi kościół pw. św. Mikołaja ulokowany był na ostrodze między wcześniej opisanym zakolem a meandrem sięgającym aż do ulicy Legnickiej.

Położenie górujące nad okolicznym terenem prawdopodobnie było uwzględnione przy budowie kościoła pw. św. Wojciecha. Obecnie trudno sobie wyobrazić, że pierwotnie od strony Nowego Targu był on wyniesiony o około $2 \mathrm{~m}$. 


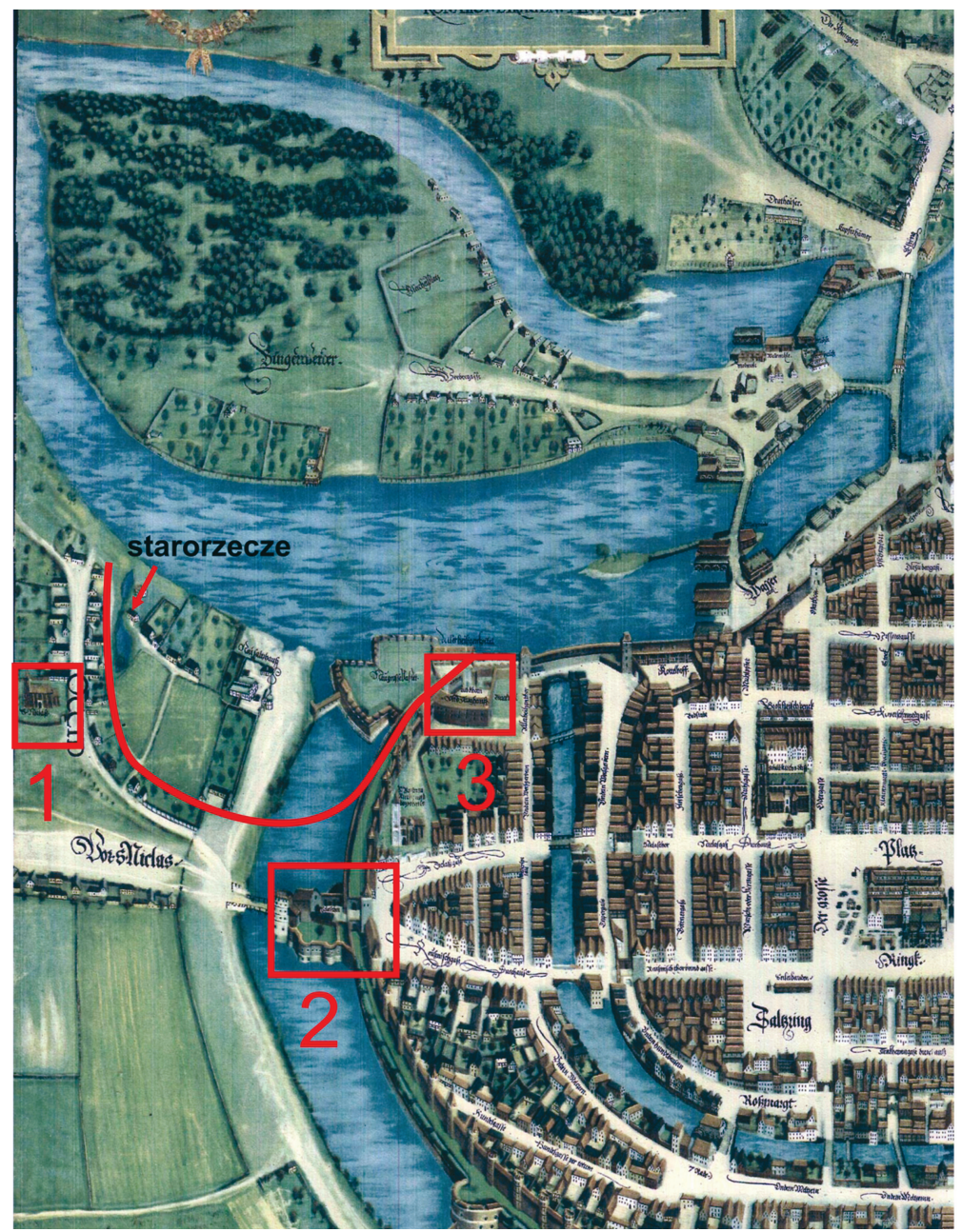

Ryc. 2. Krawędź meandra (linia czerwona) oraz starorzecze znajdujące się na południe od Placu św. Jana Pawła II. Widoczne jeziorko wypełnione wodą oraz łuk ulic Rybackiej i Długiej biegnących koroną meandra, a także zachowany do dzisiaj prawie niezmieniony kształt Kępy Mieszczańskiej. Ważne obiekty historyczne wykorzystujące nadrzeczne położenie: 1 - kościół pw. św. Mikołaja; 2 - Brama Mikołajowska; 3 - Zamek Wójtowski (oprac. J. Badura na podstawie planu B. i B. Weinerów z 1562 roku)

Fig. 2. Meander edge (red line) and oxbow lake located south of St John Paul II Square. Visible lake filled with water and the arc of Rybacka and Długa streets running along the meander's crown, as well as the shape of Kępa Mieszczańska Island preserved to this day almost unchanged. Important historical objects taking adventage of the riverside location: 1 - St Nicholas'church; 2 - St Nicholas' gate; 3 - Mayor's Castle (edited by J. Badura based of B. \& B. Weiner's city map from 1562) 
Od wschodu tuż przy kościele koryto Oławy ostro skręcało ku północy do Odry. Później ten fragment koryta Oławy wykorzystano do zasilania wewnętrznej fosy miejskiej. Podobnie wykorzystując bliskie brzegi Odry ulokowane były opactwo św. Wincentego na Ołbinie, a także pierwsza siedziba książąt na Ostrowie Tumskim. Ta ostatnia znajdowała się tuż przy ujściu Odry Szczytnickiej Północnej do Odry, więc można było dostać się do niej tylko od strony wschodniej (ryc. 3, 4). W tak zmieniających się warunkach przyrodniczych powstały zamki - pierwszy grodowy, kolejne - miejskie (ryc. 5-7).

\section{Zamek książęcy na Ostrowie Tumskim}

Pierwszym miejscem powstania rezydencji władzy książęcej we Wrocławiu był gród na Ostrowie Tumskim (ryc. 5: a), który od 2. połowy X wieku funkcjonował jako stolica prowincji (Żurek 1996, s. 24, ryc. 4). Przebieg drewniano-ziemnych wałów grodu nie został jednoznacznie wytyczony, również lokalizacja książęcej siedziby z XI-XII wieku jest przybliżona, mimo prowadzonych na tym terenie badań archeologicznych. Problem dotyczy również umiejscowienia w obrębie grodu kaplicy św. Piotra, wzmiankowanej od 1175 roku (Żurek 1996, s. 26-27, ryc. 3; Chorowska 2014, s. 138; 2017, s. 42). W 2. połowie XII wieku grodem zarząazał piastowski książę Bolesław Wysoki (lata 1163-1201), który powrócił na Śląsk z wygnania w Altenburgu po 1163 roku. W tym czasie, po północno-wschodniej stronie grodu, w miąższu istniejących wałów drewniano-ziemnych dwuczłonowej warowni na Ostrowie, powstała nietypowa murowana, osiemnastoboczna budowla wieżowa (faza I, lata 1166-1186) o zewnętrznej średnicy 24,5 m (ryc. 5: d). Składała się z 18 trapezoidalnych filarów rozmieszczonych po obwodzie oraz cylindrycznego środkowego filaru o średnicy około $3 \mathrm{~m}$; tworzyły one pierścień o grubości 2,5 m. Wewnętrzna średnica budowli wynosiła około $20 \mathrm{~m}$ i, jak wynika z obliczeń konstruktorów, mogła mieć do $20 \mathrm{~m}$ wysokości (Chorowska 2014, s. 143-147, ryc. 10; 2017, s. 41, plansza 6). W 4. ćwierci XII wieku (w 1172 lub 1177 roku?) górna część osiemnastobocznej budowli została uszkodzona w wyniku gwałtownych zdarzeń połączonych z pożarem. Po nich od strony północnej i północno-wschodniej wieża została otoczona murem płaszczowym, umieszczonym głębiej w istniejącym wale drewniano-ziemnym, zabezpieczając wieżę od strony Odry (ryc. 5: b, d). Mur ten, oddalony od wieży o 1,0-1,6 m, od strony zewnętrznej zabezpieczony został nowym, oskarpowanym wałem drewniano-ziemnym o szerokości u podstawy co najmniej $7 \mathrm{~m}$ (faza II, lata 1175-1200) (Chorowska 2014, s. 147-150, ryc. 10). Na południowy wschód od wieży powstał na przełomie XII i XIII wieku dwuizbowy, prostokątny budynek 


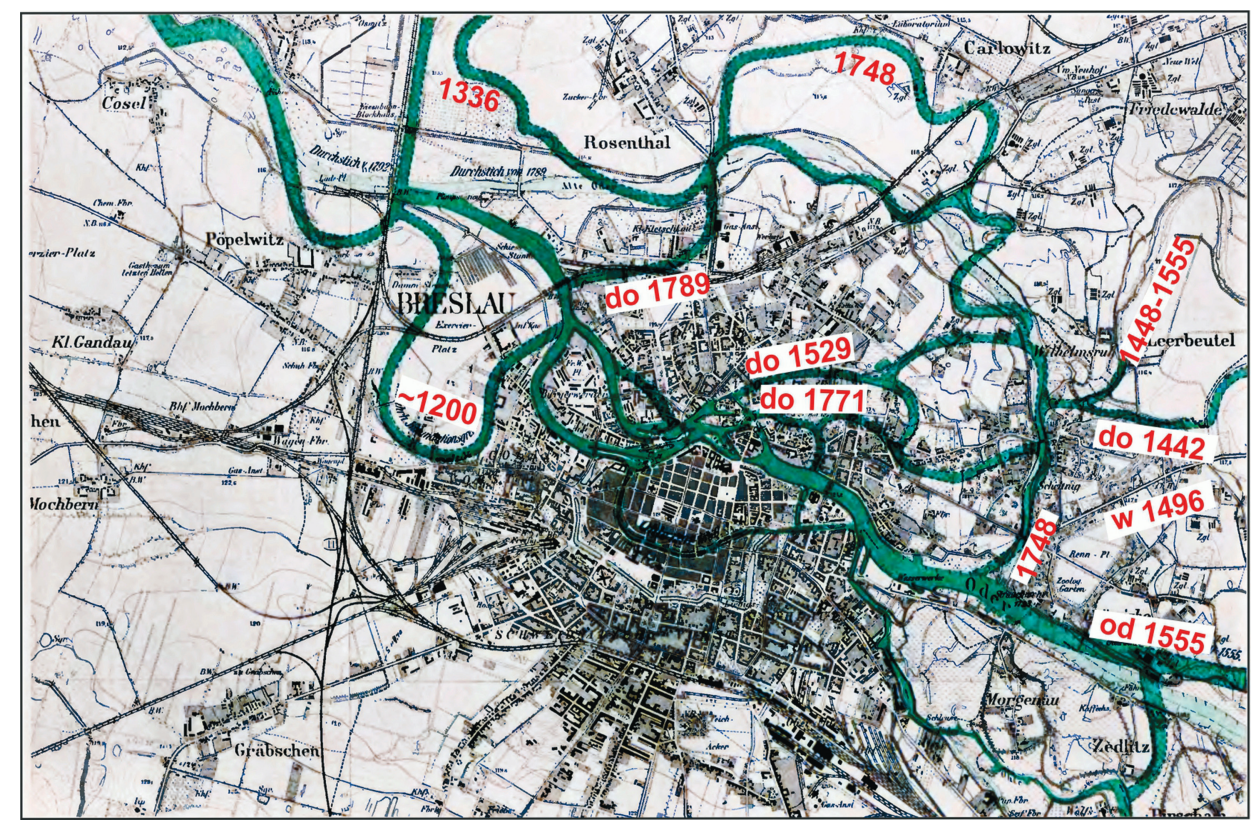

Ryc. 3. Przebieg starych koryt Odry przedstawiony na pocztówce opracowanej przez Richarda Leonharda w 1901 roku, ilustrującej fenomen hydrograficzny Wrocławia jako miasta wielu wysp. Daty informują, w jakim czasie dany fragment koryta Odry był czynny lub kiedy dane koryto zamarło (wg Leonhard 1901, Blatt 44; oprac. J. Badura)

Fig. 3. The course of the old Odra River channels presented on a postcard edited by Richard Leonhard in 1901, illustrating the hydrographic phenomenon of Wrocław as the town of many islands. The dates indicate when a specific section of the Odra River was active or when the given riverbed stopped (after Leonhard1901, Blatt 44; edited by J. Badura)

o przypuszczalnych wymiarach $14,3 \times$ około $30 \mathrm{~m}$, ogrzewany piecami hypokaustycznymi (faza III, około 1200 roku, ryc. 5: c, e) ${ }^{1}$.

Za czasów panowania Henryka I Brodatego (lata 1201-1238), nastąpił kolejny etap prac budowlanych (faza IV, do 1212 roku). Na wschód od osiemnastobocznej wieży powstała $\mathrm{w}$ dwóch etapach podpiwniczona budowla na planie kwadratu o boku około 17 m (faza V; Chorowska 2017, s. 41, plansza 6). Prawdopodobnie była to oskarpowana wieża (donżon), która przejęła funkcje obronne osiemnastobocznego obiektu. Wzniesiono ją na częściowo rozebranym w północnej części budynku z fazy III. W wyniku następnej przebudowy powstał monumentalny

${ }^{1}$ Pierwotnie budynek był interpretowany jako klasztor opactwa św. Marcina (Żurek 1996, s. 35), należałoby jednak widzieć go jako dom związany z dworem księcia, zwłaszcza, że powstał w czasie powiększenia zamku, tj. przesunięcia wału, oddzielającego gród od podgrodzia na wschodzie (Chorowska 2014, s. 150, 161; 2017, s. 41, plansza 6). 


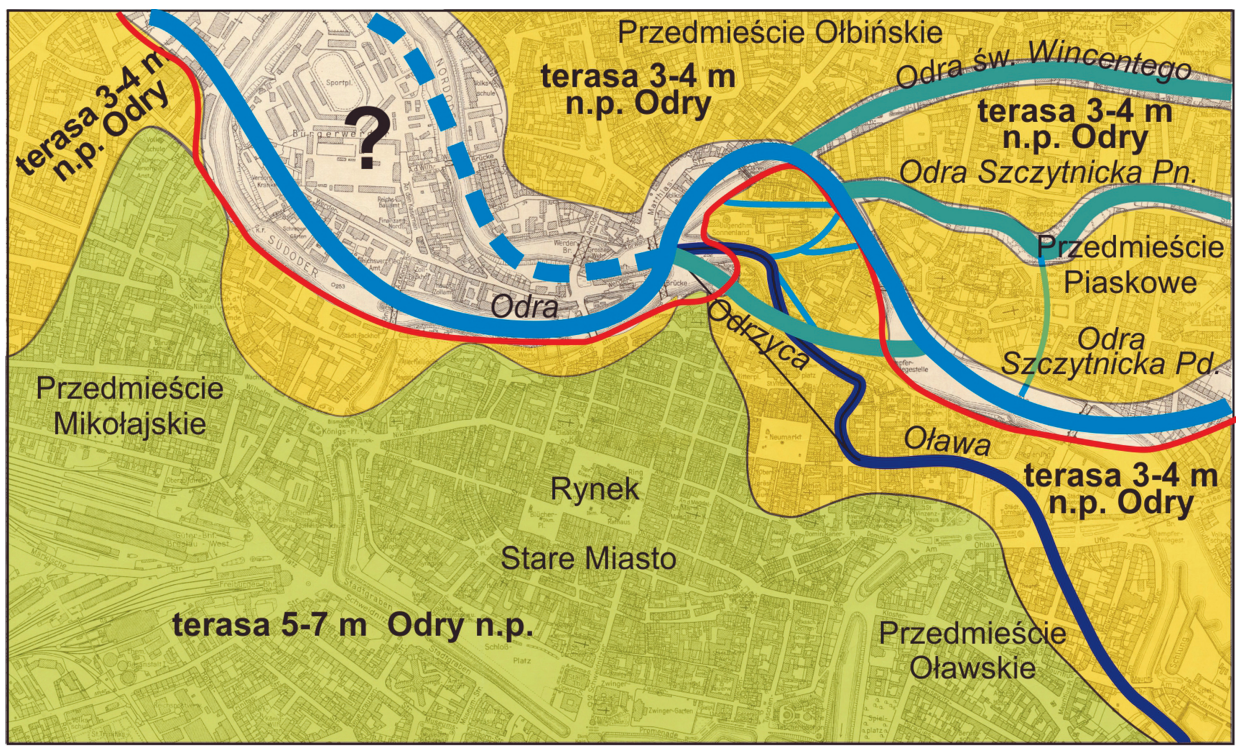

Ryc. 4. Przypuszczalny kształt zakoli meandrowych Odry w rejonie średniowiecznego Wrocławia oraz miejsce awulsji (Odrzycy) i sztucznych przekopów (linie jasno niebieskie) (oprac. J. Badura)

Fig. 4. The supposed shape of the meanders of the Odra River in the area of medieval Wrocław as well as the place of the avulsion (Odrzyca) and artificial ditches (light blue lines) (edited by J. Badura)

pałac, który ze wspomnianą narożną wieżą miał długość około $70 \mathrm{~m}$. Utworzony został na miejscu rozebranego po stronie południowej osiemnastobocznego obiektu, którego północna część włączona została w obręb powstałego pałacu (Chorowska 2014, s. 151-153, 161, ryc. 10, 11; 2017, s. 41, plansza 6) ${ }^{2}$. W tym czasie zbudowana została ośmioboczna kaplica z trzema absydami i kwadratowym prezbiterium zakończonym czwartą absydą (ryc. 5: f) $)^{3}$.

W fazie VI (około 1250 roku) zamek został otoczony murem obwodowym o poligonalnym zarysie (ryc. 5: g). Obwód obronny był posadowiony na kulminacji już osiadłych wałów lub wychodził poza nie, powiększając obszar zamku do około $9000 \mathrm{~m}^{2}$. Odcinki południowy i wschodni muru wzniesione zostały na ławie fundamentowej filarowo-łękowej, o grubości od 0,90 do 1,35 m. Mury bez skarp miały wzmocnienia w postaci czworokątnych baszt flankujących, z których wschodnia przybramna miała wymiary 6,2 ×7,0 m (Małachowicz 1993, s. 81-83; Chorowska 2014, s. 155; 2017, s. 41, plansza 6). Północny odcinek muru obronnego

\footnotetext{
${ }^{2}$ W założeniu pałacowym Henryka Brodatego rezydował Henryk Pobożny (w latach1238-1241) i Henryk III Biały (w latach1248-1266), o czym świadczą dokumenty odwołujące się do zamku lub jego komnat (Żurek 1996, s. 58, 70, przypisy 34, 35).

${ }^{3}$ Relikty kaplicy odkryte zostały w 1970 roku przez Edmunda Małachowicza i Czesława Lasotę (Małachowicz 1993, s. 36-38).
} 

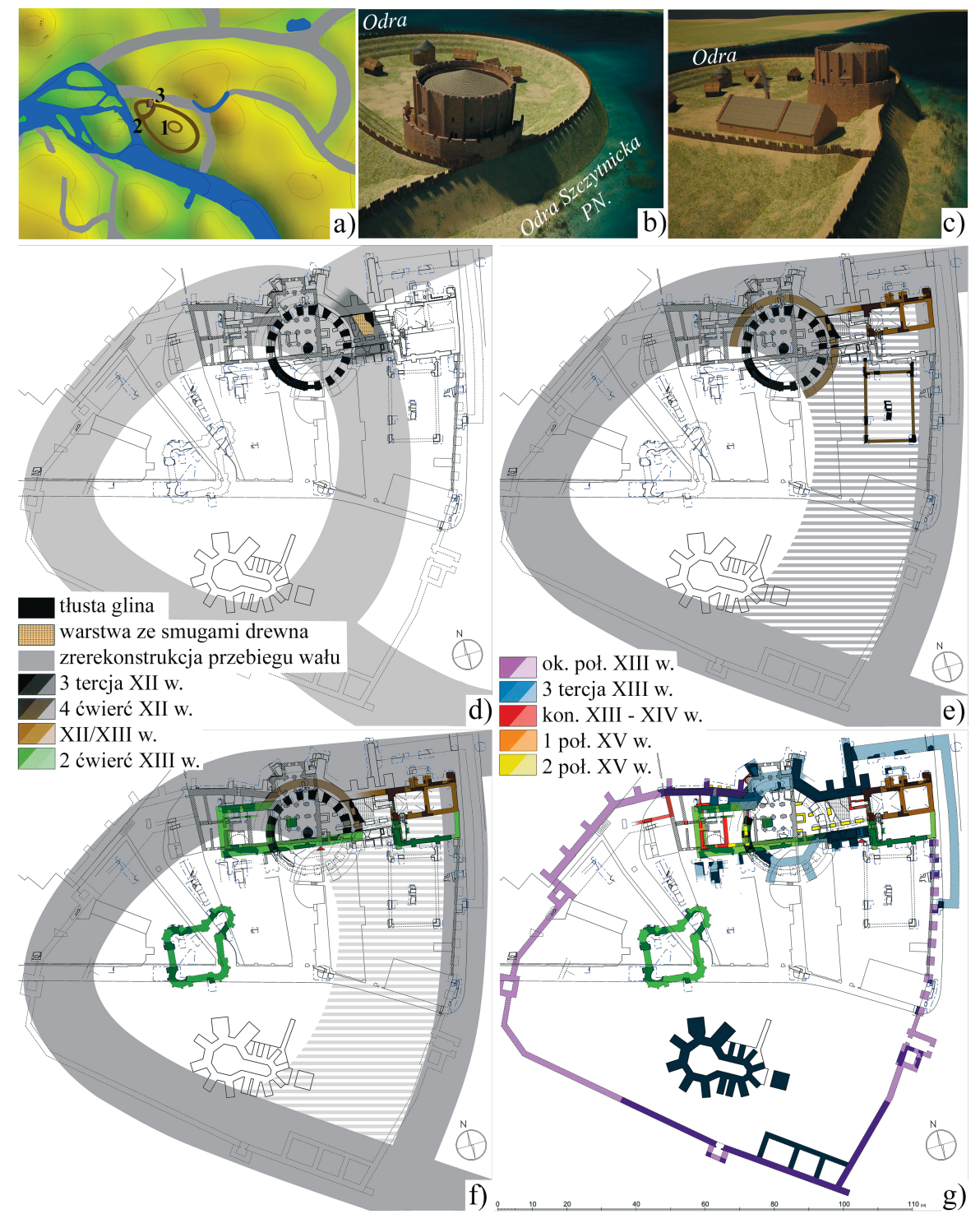

Ryc. 5. Wrocław, Ostrów Tumski. a - najstarsza wieża (3) na tle grodu z X wieku (1) i XII wieku (2); b, c - wizualizacja najstarszych faz zamkowych. Fazy rozwoju zabudowy zamku: d - faza 1; e - faza 4; f faza 5; g - faza 7 (a - oprac. T. Kastek; b-c-oprac. M. Krzywka; d-g - wg Chorowska 2017)

Fig. 5. Wrocław, Ostrów Tumski. a - the oldest tower (3) against the background of the stronghold from the $10^{\text {th }}$ century (1) and $12^{\text {th }}$ century (2); b, c - visualisation of the oldest castle phases. Phases of castle development; $d$ - phase 1; e - phase 4; $\mathrm{f}$ - phase 5; $\mathrm{g}$ - phase 7 ( $\mathrm{a}$ - edited by T. Kastek; b-c - edited by M. Krzywka; d-g - after Chorowska 2017) 
o grubości $2 \mathrm{~m}$, posadowiony na ciągłej ławie fundamentowej, wzmocniony był skarpami o wymiarach 2,6×1,5 m, rozmieszczonymi co 10-11 m. Pierwotna jego wysokość dochodziła do $11 \mathrm{~m}$ (od posadowienia - 115,3 m n.p.m. do poziomu ganku bojowego).

Ostatnia wielka przebudowa w ,nowy” pałac miała miejsce za czasów Henryka IV Probusa (lata 1270-1290), jednak rozpoczęcie prac mogło nastąpić już za panowania Władysława Salsburskiego (lata 1266-1270). W jej wyniku powstał prostokątny pałac przenikający się z oktagonalnym obiektem umiejscowionym pośrodku założenia; wszystko zaś było opięte potężnymi przyporami (faza VII, lata 1270-1290, ryc. 5 g, ryc. 7: f). Długość skarp dochodziła do 5,5 m, szerokość do $3 \mathrm{~m}$. Założenie pałacowe o długości około $50 \mathrm{~m}$, miało wybudowany w miejscu dawnej osiemnastobocznej budowli ośmioboczną, o przekątnej 17,6 m. Dzięki temu miało dwie osie symetrii - podłużną i poprzeczną. Założenie to prawdopodobnie było połączone gankiem na arkadowym fundamencie z kaplicą o czterech absydach oraz z kaplica pw. św. Marcina, ufundowaną przez Henryka Probusa (Chorowska 2014, s. 157-159, ryc. 15; 2017, s. 41, plansza 6).

Założenie z czasów Henryka Brodatego, jak i pałac przebudowany za czasów Henryka Probusa, swą topografią nawiązywały do obiektów pałacowych w Akwizgranie. Takie rozwiązania występują między innymi w zamkach Ortenburg (Budziszyn, Niemcy), Tancaville i Uchaux (Francja) (Chorowska 2014, s. 162; 2017, s. 42).

Przeobrażanie się zamku na Ostrowie Tumskim na przestrzeni XII i XIII wieku następowało na w miarę ograniczonym obszarze, wyznaczonym przez drewniano-ziemne wały wczesnośredniowiecznego grodziska. Niewielkie zmiany tych obwarowań zachodziły w części północno-wschodniej grodziska, gdzie następowały zmiany z przesuwaniem obwarowań ziemnych otaczających założenie zamkowe ${ }^{4}$. Nie były one jednak wielkie, gdyż jak przypuszcza J. Badura, wyspa ta powstała w wyniku przekopania fosy - łącznika między dwoma ramionami Odry.

\section{Zamek lewobrzeżny}

W czasie funkcjonowania i przeobrażania się zamku na Ostrowie Tumskim, na lewym brzegu Odry powstały kolejne siedziby książęce (ryc. 7: f). Podczas kształtowania się książęcego ośrodka władzy na tych terenach, zaczął kształtować się nowy twór - ośrodek miejski.

Pierwszą lewobrzeżną budowlą książęcą był zamek funkcjonujący w miejscu późniejszej siedziby Karola IV (lata 1346-1378), znanej ze wspomnianego wyżej

\footnotetext{
${ }^{4}$ Zmiany rozwoju koncepcji kształtowania się wałów wokół Ostrowa Tumskiego zebrała Aleksandra Pankiewicz (2015, s. 13-31, ryc. 1-4, 8). Nowe spojrzenie na obwarowania grodu tumskiego przyniosły badania georadarowe przeprowadzone przez Adama Szynkiewicza z zespołem (Limisiewicz, Pankiewicz, Szynkiewicz 2015, s. 33-54, ryc. 1).
} 

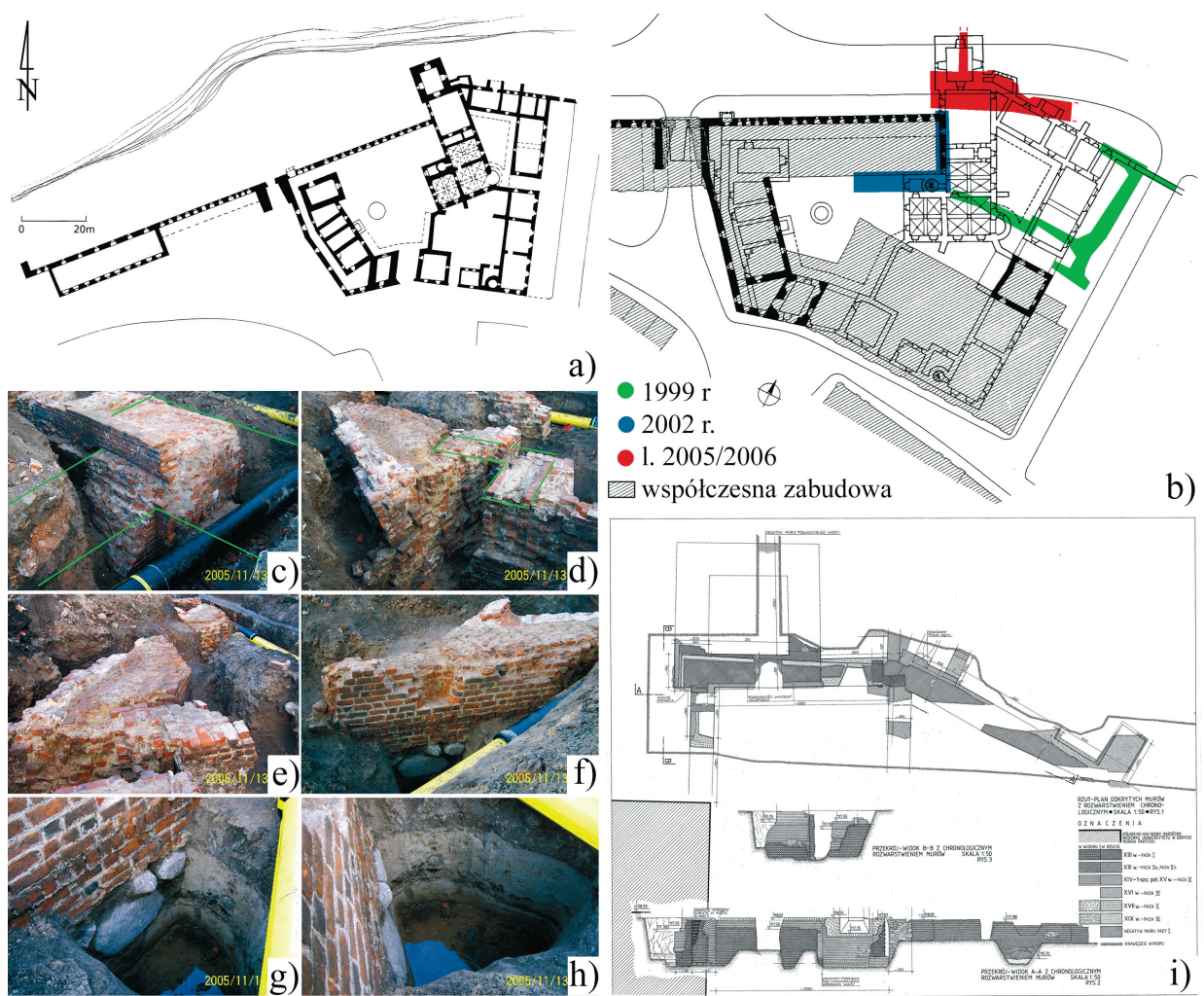

Ryc. 6. Wrocław, zamek lewobrzeżny: a - plan zamku według K. Bimlera (1933); $\mathrm{b}$ - relikty zamku na tle współczesnej zabudowy; c-południowo-wschodni narożnik czworobocznej wieży; d - przypory krzyżowe pierwszego palatium; e - wschodni odcinek XIII-wiecznego muru obronnego; f-południowe lico XIII-wiecznego muru obronnego; $\mathrm{g}-\mathrm{h}$ - nasypy piaszczyste, w które wkopany jest XIII-wieczny mur obronny; i - rzut i profile dokumentujące odkrycie wieży czworobocznej i pierwszego palatium ( $b-$ Kmiecik, Szwed w druku; c-h - fot. R. Mruczek; i-oprac. J. Burnita, Cz. Lasota, P. Konczewski, J. Piekalski)

Fig. 6. Wrocław, left bank castle: a - castle plan after K. Bimler (1933); b-relics of the castle against the background of contemporary buildings; c - south-eastern corner of the quadrilateral tower; $\mathrm{d}$ - cross buttresses of the first palatium; $\mathrm{e}$ - eastern section of the $13^{\text {th }}$-century defensive wall; $f$ - southern face of the $13^{\text {th }}$-century defensive wall; $\mathrm{g}-\mathrm{h}$ - sandy embankments in which the $13^{\text {th }}$-century defensive wall was dug; $\mathrm{i}$ - plan and sections documenting the discovery of the quadrilateral tower and the first palatium $(\mathrm{b}-\mathrm{Kmiecik}$, Szwed in print; $\mathrm{c}-\mathrm{h}-$ photo by R. Mruczek; edited by J. Burnita, Cz. Lasota, P. Konczewski, J. Piekalski) 
planu B. i B. Weinerów, także ikonografii F. H. Vrooma i F. Grossa z 1587 roku, G. Hayera z 1591 roku czy też M. Meriana z 1641 roku (Wrocław 1999, plansza 5; Atlas historyczny 2001, plansze 13, 14,15). Jako najstarszy zamek lewobrzeżny Kurt Bimler widział założenie dwuczłonowe. Składało się ono z zamku górnego, zawierającego cylindryczną wieżę typu bergfried (w północnej części), budynek pałacowy, kuchnię, izby służebnych, studnię i pomieszczenia pańskie, zamknięte w trójkąt. Drugi człon - podrzędny, w zachodniej części, zawierał lekką wieżę w północnej części i dziedziniec pełniący funkcję gospodarczą. Bergfried miał znajdować się na styku obu członów (ryc. 6: a). Wspomniany autor założenie zamkowe określał jako romańsko-wczesnogotyckie, funkcjonujące w XII-XIII wieku (Bimler 1933, s. 15).

Badania w okresie powojennym tylko w niewielkiej części odsłoniły założenie zamkowe; nie poznano stratygrafii najstarszego osadnictwa w tym rejonie $^{5}$. Kolejne prace, przeprowadzone w latach 1999-2003 oraz 2005-2006 (ryc. 6: b, i), pozwoliły zidentyfikować najstarsze fazy rozwoju zamku, mimo, że nie objęły całego obszaru ani też nie rozpoznano pełnej stratygrafii nawarstwień archeologicznych (Mruczek, Stefanowicz 2000, s. 237-251; Mruczek i in. 2003; Mruczek, Nowakowski, Stafanowicz 2005, s. 175-191; Konczewski, Lasota, Piekalski 2007, s. 225-253; 2014, s. 201-211). Na podstawie wyników tych badań, uznano, że pierwszym obiektem, który powstał była czworoboczna w rzucie wieża o wymiarach 8,60×8,45 m i grubości ścian do $2 \mathrm{~m}$ (ryc. 6: c, e). Do obiektu tego dostawiony został budynek pełniący funkcję palatium. Kolejne przebudowy pałacu przeprowadzono w tym samym miejscu co budynek z najstarszej fazy, co spowodowało, że zniknęly relikty z fazy palatium. Zachowały się one jedynie w szczątkowej formie w XIII-wiecznym murze obronnym, który wchłonął północno-zachodnie przypory palatium (ryc. 6: d). Mur miał szerokość 13,0 m i ściany grubości $1,40 \mathrm{~m}$.

Prawdopodobnie w czasie funkcjonowania czworobocznej wieży wraz z palatium powstała brama zabezpieczająca przeprawę przez Odrę. Jej usytuowanie w tym miejscu wynikało z konfliktu w latach 1230-1231, między księciem Henrykiem Brodatym a kanonikami regularnymi z Piasku i norbertanami z Ołbina. Dotyczył on starej przeprawy istniejącej w miejscu późniejszej Bramy Piaskowej. Znajdował się tam główny szlak północ-południe, biegnący z lewobrzeżnych terenów książęcych na wyspę Piaskową i dalej na targowy Ołbin ${ }^{6}$. Nie wiemy, gdzie znajdowała się pierwsza przeniesiona przeprawa. Czy było to miejsce powstania późniejszej Bramy Cesarskiej, czy też teren po stronie wschodniej wieży zamkowej,

\footnotetext{
${ }^{5}$ Pierwsze badania przeprowadzono w latach 1954-1957 przez zespół Mariana Morelowskiego i Józefa Kaźmierczyka (Morelowski 1955, s. 10-16; Kaźmierczyk 1957, 192-193; 1959a, 223-245).

${ }^{6}$ Przeniesienie przeprawy na zachód miało również skutki związane z powstawaniem XIIIwiecznych obwarowań miejskich. W miejscu, gdzie wcześniej istniała stara przeprawa powstała baszta, która zablokowała komunikację z terenami klasztornymi (Romanow 2001, s. 134-138; Kastek, Mruczek 2016, s. 15).
} 
skoro w 1231 roku wzmiankowany był przewóz przez Odrę, znajdujący się na wschód od zamku (Mruczek, Nowakowski, Stefanowicz 2005, s. 175).

Do istniejących zabudowań książęcych dostawiony został w połowie XIII wieku miejski obwód obronny, który obejmował istniejące już założenie pałacowe i stykał się ze wspomnianą wieżą od strony wschodniej. Odcinek miejskiego muru obronnego, dochodzący do założenia pałacowego od zachodu, został cofnięty w kierunku południowym od Odry o prawie $7 \mathrm{~m}$ i łączył się z budynkiem pałacowym (ryc. 6: a). Ten XIII-wieczny obwód obronny (ryc. 6: f-h) w północnej i wschodniej części miasta posadowiony był na piaszczystych nasypach (ryc. 6: g, h) ${ }^{7}$, które można interpretować jako stabilizację podłoża brzegu Odry pod przyszłe budowle lub też jako wał ziemny (przeciwpowodziowy, obronny?) starszy od murów w obrębie założenia zamkowego, identyfikowany wokół tzw. wielkiej lokacji Wrocławia (Rozpędowski 1995, s. 41-52).

Za pierwsze wzmianki dotyczące zamku lewobrzeżnego można uznać te odnoszące się do obiektu wymienionego w tzw. pouczeniu magdeburskim (lata $\left.1211-1238^{8}\right)$. W dokumencie z 1253 roku wymieniono zniszczoną wieżę ceglaną - turris lateritia destructa ${ }^{9}$. Identyfikowana jest ona z czworoboczną wieżą, która zaadaptowana została $\mathrm{w}$ trakcie budowy rezydencji cesarskiej w XIV wieku. Był to obiekt najdalej wysunięty w kierunku Odry ${ }^{10}$. Zniszczony został prawdopodobnie w wyniku powodzi jakie nawiedzały ówczesny Wrocław ${ }^{11}$ i mogło być związane z jego ulokowaniem na brzegu rzeki, na usypanym wale ziemnym. $Z$ wydarzeniem, które miało miejsce w 1253 roku powinno się wiązać fakt rozbieżności w przebiegu murowanego obwodu miejskiego łączącego się z założeniem zamkowym. Prawdopodobnie odcinek muru miejskiego dochodzący

${ }^{7}$ Piaszczyste nasypy na terenie zamku lewobrzeżnego odkryto w latach 1954-1957 oraz 20052006 (Kaźmierczyk 1959b, s. 241-244, ryc. 1; Konczewski, Lasota, Piekalski 2007, s. 233, 238; 2014, s. 208). Natrafiono na nie także na terenach nadbrzeżnych, między innymi przy kościele pw. św. Jakuba, i w rejonie Bramy Piaskowej (Kaźmierczyk 1957, s. 117-118; 1966, s. 27). Obecnie prowadzone badania archeologiczno-architektoniczne w północno-zachodnim narożniku średniowiecznego miasta Wrocławia, na terenie dawnego Szpitala im. J. Babińskiego przy pl. Jana Pawła II, w rejonie zachodniej ściany Arsenału, przez zespół w składzie: Piotr Kmiecik, Czesław Lasota, Robert Szwed, również ujawniły takie nasypy.

${ }^{8}$ KDŚl. 2: 90-94, nr 147; SUb., t. 1, nr 321. Theodor Goerlitz datuje dokument na lata 1232-1241 (Goerlitz 1935, s. 92-105; por. też Młynarska-Kaletynowa 1986, s. 106-107).

${ }_{9}$ Prawdopodobnie wieża zamkowa zlokalizowana na terenie kurii św. Anny pojawiła się w dokumencie fundacyjnym szpitala św. Elżbiety z 1253 roku: item pars curie domine matris nostre usque ad turrem latericeam destructam post obitum eiusdem (SUb., t. 3, nr 60, 61; SUb., $\mathrm{nr}$ 17).

${ }^{10} \mathrm{~W}$ trakcie badań archeologiczno-architektonicznych zidentyfikowano uszkodzenie wieży na poziomie fundamentów.

${ }^{11} \mathrm{~W}$ tym czasie, tj. w XII i XIII wieku zarejestrowano pięć powodzi, które spowodowało na tyle duże szkody, że zostały odnotowane w kronikach (Kasprzak 2010, s. 106). Temat powodzi został poruszony przez J. Badurę podczas badań archeologicznych prowadzonych na Placu Wolności i odkrywaniem w tej części miasta tzw. depresji powodziowych (Badura 2009, s. 2-5; Badura i in. 2010, s. 381-384). 
do zamku od strony wschodniej był wykonany przed wspomnianą powodzią, natomiast odcinek zachodni został skorygowany w wyniku tragedii budowlanej i odsunięty od brzegu rzeki w kierunku miasta ${ }^{12}$. W latach 1895-1897, w trakcie budowy Gmachu Chemii przy ul. Grodzkiej, odkryto (w 1896 roku) fundamenty wieży cylindrycznej o murach czterometrowej grubości, która nie istniała już w 1350 roku, kiedy budowany był zamek cesarski dla Karola IV (Bimler 1933, s. 15; Mruczek, Nowakowski, Stefanowicz 2005, s. 178).

Analizując zmiany związane z zagospodarowywaniem i zasiedlaniem lewobrzeżnych obszarów Odry i Oławy, należy zwrócić uwagę na fakt, że pierwotnym ciekiem oddzielającym tereny książęce, miejskie od Ołbina, Ostrowa Tumskiego $\mathrm{i}$ innych wysp była Oława. Wspomniana jest ona w dokumencie lokacyjnym z 1263 roku, w którym pojawia się zwrot: et muros arcis nostre Wratizlavie, atque ripam fluminis Olawe (,między murami zamku naszego Wrocławia i brzegiem Oławy; (SUb., t. 3, nr 436; Mruczek, Nowakowski, Stefanowicz 2005, s. 175). Zwrócił na to uwagę Jerzy Romanow, który prowadził badania archeologiczne na terenach Bramy Piaskowej i szpitala św. Ducha. Badacz odkrył tam ceglany chodnik łączący tereny lewobrzeżnego miasta ze wspomnianym szpitalem, zbudowany w miejscu dawnego koryta Oławy (Romanow 2001, s. 133-147; Romanow, Romanow 2010, s. 171-173).

\section{Zamek lewobrzeżny (II), Arsenat Miejski}

Drugi z zamków lewobrzeżnych miał powstać w miejscu później istniejącego Arsenału Miejskiego (ryc. 7: f), w latach 1459-1741 (Bukowski 1979; Burak 2012). Znajdował się w północno-zachodnim narożniku miasta lokacyjnego z 1261 roku. W okresie funkcjonowania miasta, miejsce nazywane było Burgfeld, Burgwall. Relikt pierwszego murowanego obiektu fortyfikacyjnego, rozpoznanego w wyniku badań archeologiczno-architektonicznych, miał powierzchnię około $132 \times 70 \mathrm{~m}$. Jerzy Romanow do tego założenia zaliczył czworoboczną wieżę o wymiarach $8,50 \times 8,9 \mathrm{~m}$ wraz ze ścianami późniejszego Arsenału: północną, wschodnią i południową na poziomie fundamentów (Romanow 1979; 1992; 1994; Piszczałkowski 1982, s. 277-278; Piwko, Romanow 1994; 1996). Widział on w narożniku północno-wschodnim, gdzie znajdowała się apteka szpitala, powielony północny obwód tworzący rodzaj parchamu, przy wschodniej ścianie, w narożnikach południowo-wschodnim i północno-wschodnim - narożne wieże, baszty(?), po stronie zachodniej rekonstruował przejazd bramny (ryc. 7: a). Zamek od wschodu otoczony był fosą miejską, od południa i zachodu fosą zamkową, która później stała się fosą miejską - zewnętrzną. Badacz interpretował odkrycie jako niedokończony zamek Henryka IV (Romanow 1979; Małachowicz 1994, s. 24).

${ }^{12}$ Brak pełnych badań archeologicznych oraz zniszczenie obwodu obronnego od strony zachodniej w wyniku powstania budynku Uniwersytetu Wrocławskiego, nie pozwala na potwierdzenie tych przypuszczeń. 

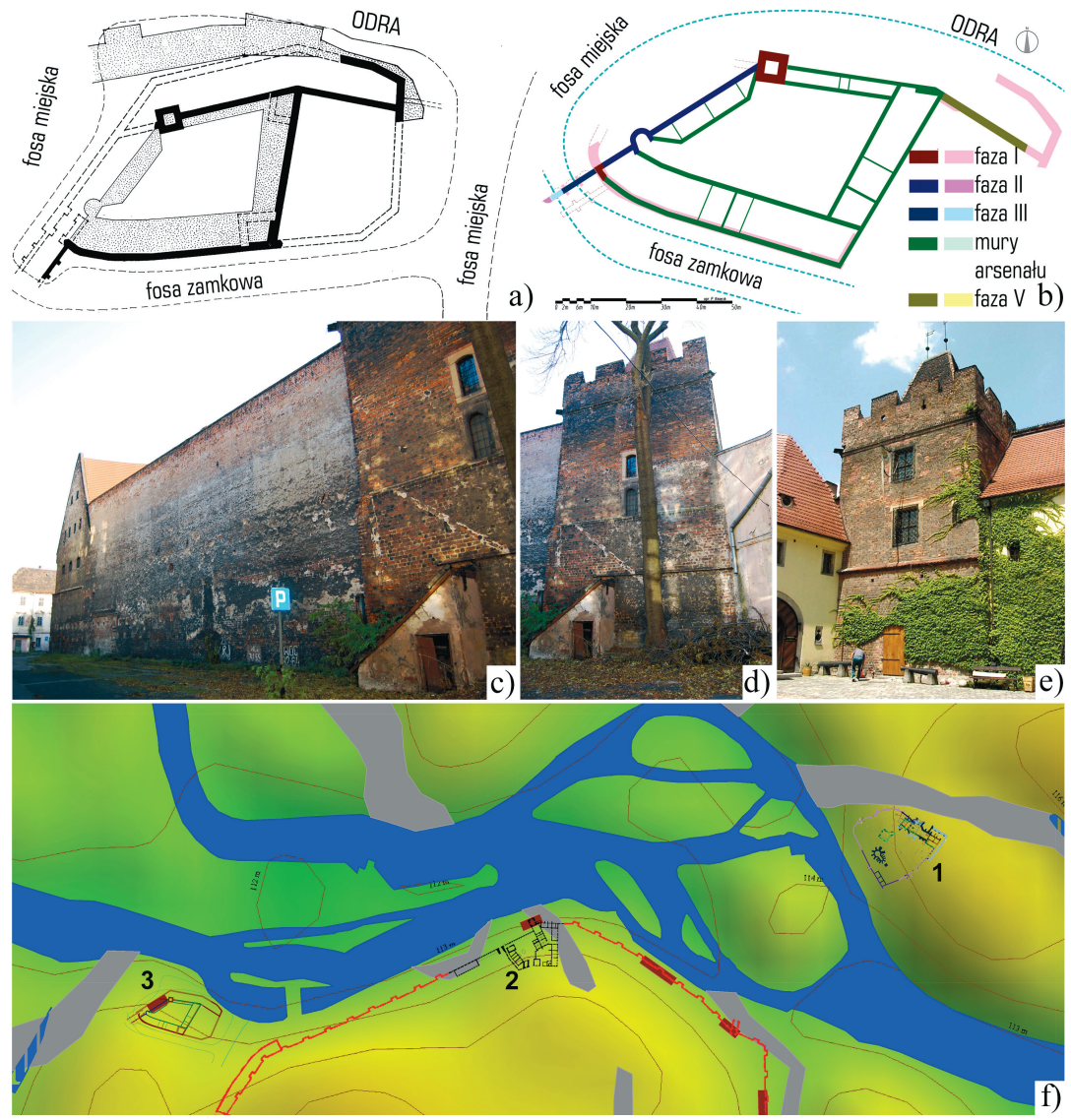

Ryc. 7. Wrocław, zamek lewobrzeżny II (Arsenał): a - relikty zamkowe według J. Romanowa; b - wstępne rozwarstwienie murów zamkowych według P. Kmiecika, Cz. Lasoty i R. Szweda; c - północna ściana Arsenału postawiona na fundamentach zamkowych; d - widok od strony północnej na wieżę czworoboczną; e - widok od strony południowej na wieżę czworoboczną (fot. R. Mruczek); $\mathrm{f}$ - rozmieszczenie wrocławskich zamków na tle naturalnego poziomu próchnicznego ( 1 - zamek na Ostrowie Tumskim, 2 - zamek lewobrzeżny, 3 - zamek lewobrzeżny II - Arsenał) (c, d - fot. T. A. Kastek; e - fot. R. Mruczek; f - oprac. J. Badura, T. A. Kastek)

Fig. 7. Wrocław, left bank castle II (Arsenal): a - castle relics after J. Romanow; $\mathrm{b}$ - preliminary stratification of the castle walls after P. Kmiecik, Cz. Lasota and R. Szwed; c - northern wall of the Arsenal built on the foundations of the castle; $\mathrm{d}$ - a view from the north to the quadrilateral tower; e - view from the south to the quadrilateral tower (photo by R. Mruczek); f - location of Wrocław castles against the background of the natural humus level (1 - Ostrów Tumski castle; 2 - left bank castle; 3 - left bank castle II - Arsenal) (c, d - photo by T. A. Kastek; e - photo by R. Mruczek; f - edited by J. Badura and T. A. Kastek) 
Obecnie prowadzone prace modyfikują interpretację J. Romanowa ${ }^{13}$. Odkrycia dokonane po zachodniej stronie obecnego Arsenału wskazują na to, że nie było tu bramy, a odsłonięta przez wspomnianego badacza południowa ściana Arsenału ${ }^{14} \mathrm{~W}$ południowo-zachodnim narożniku zakręca w kierunku północnym, prawdopodobnie do zachodniej ściany czworobocznej baszty. W późniejszym czasie ten niedokończony odcinek południowej ściany został połączony ze wspomnianą basztą czworoboczną obwodem obronnym z półokrągłą basztą łupinową (ryc. 7: c-e). Prawdopodobnie odkryte mury obwodowe ze strzępiami oraz baszta czworoboczna stanowią element nieukończonej inwestycji książęcej, na której fundamentach powstał w późniejszym czasie Arsenał. W trakcie prac przy zachodniej ścianie Arsenału natrafiono na pozostałości piaszczystych nasypów zalegających na naturalnym poziomie próchnicznym. W nasypy wkopane były fundamenty odkrywanych budowli. Powstające murowane obwarowania miejskie zewnętrznego obwodu objęły teren założenia zamkowego, dochodząc do niego od strony wschodniej - obwodu XIII-wiecznego - oraz od południowej. W miejscu, gdzie znajdowała się wspomniana południowa fosa zamkowa, mur poprowadzony został na filarach (nad fosą) i dostawiony do już zabudowywanego (zabudowanego) terenu (ryc. 7: b).

\section{Miasto}

W tle powstających lewobrzeżnych siedzib książęcych kształtuje się nowe miasto lokacyjne. Wielu badaczy Wrocławia za początki nowego ośrodka miejskiego uważa lokację Wrocławia przeprowadzoną w 1241/1242 roku przez księcia Bolesława Rogatkę oraz późniejszą relokację przeprowadzoną w 1261 roku (ryc. 8: b) przez księcia Henryka III Białego i biskupa Salzburskiego Władysława na prawie magdeburskim (SUb., t. 2, nr 229, s. 138-139, t. 3, nr 373-374, s. 241-243; Młynarska-Kaletynowa 1986, s. 100-121).

W natłoku koncepcji związanych z powstaniem miasta, pojawia się jedna, przedstawiona przez J. Rozpędowskiego (ryc. 8: a), zdaniem którego tworzyło się ono na lewobrzeżnych terenach już za czasów Henryka I Brodatego (Rozpędowski 1995, s. 41-50; 2011, s. 127-138) ${ }^{15}$. Finał tego procesu mógł nastąpić

\footnotetext{
${ }^{13}$ Uprzejmie dziękujemy za udostępnienie niepublikowanych materiałów z badań obecnie prowadzonych w tym rejonie przez dr. P. Kmiecika i dr. R. Szweda, z udziałem dr. Cz. Lasoty. Umożliwiło to ponowne przeanalizowanie rozplanowania tej części zamku.

${ }^{14}$ Ściana ta zakończona została strzępiami na poziomie ławy fundamentowej oraz partii ceglanej.

15 Autor wymienia argumenty za tzw. wielką lokacją Wrocławia, między innymi: pojawienie się nazwy civitas Vratislaviensis już w 1204 roku, pojawienie się sołtysów Godinusa w 1214 roku i Aleksandra w 1229 roku, przeniesienie jarmarku ołbińskiego do lewobrzeżnego miasta w 1232 roku oraz niesymetryczne usytuowanie dużego Rynku, nieproporcjonalnego do lokacji z 1241 roku, a który idealnie wpasowywałby się w obszar założenia miejskiego identyfikowanego z terenem tzw. wielkiej lokacji. Założenia te zaczęły potwierdzać się w czasie odkrywania nasypów piaszczysto-faszynowo-ziemnych.
} 

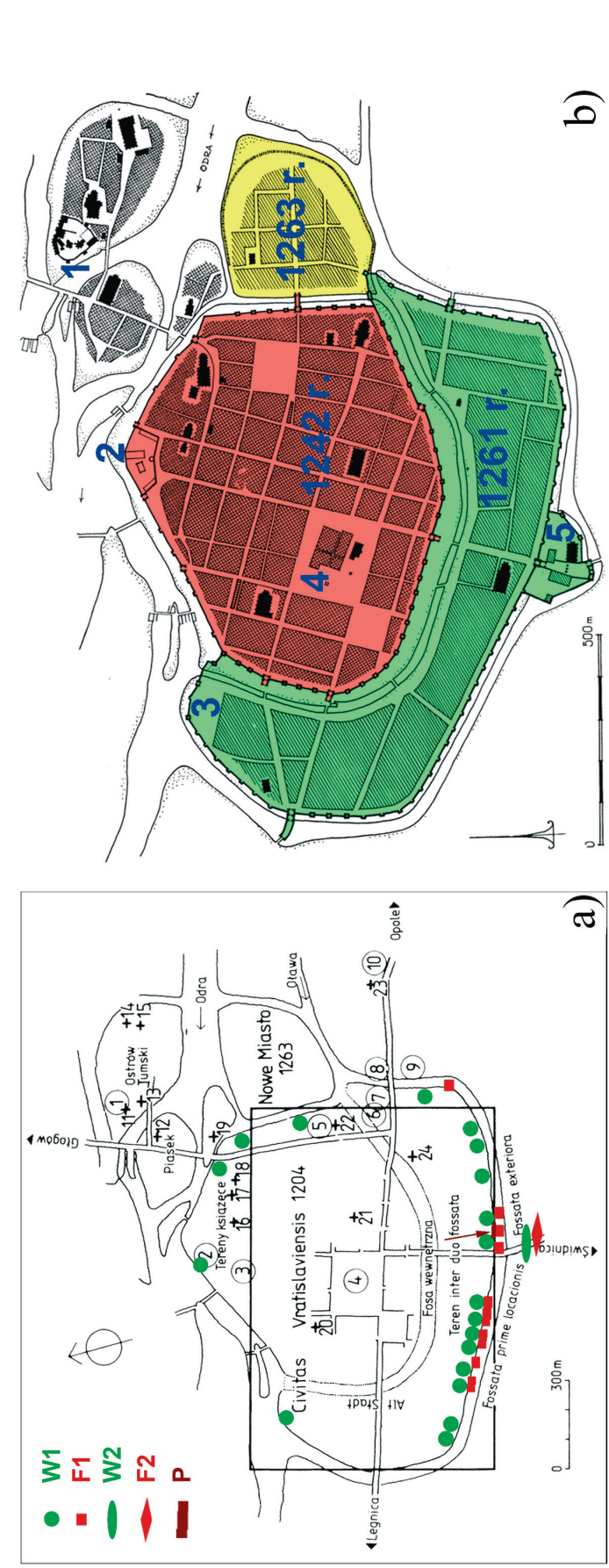

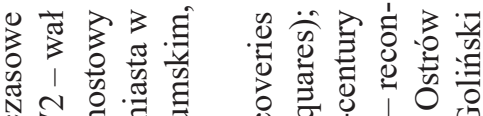

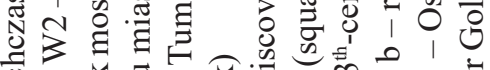

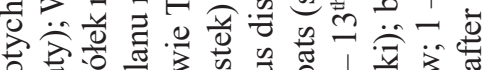

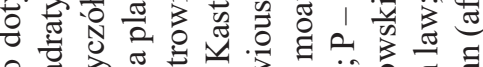

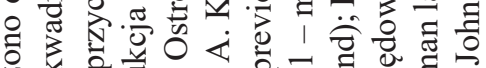

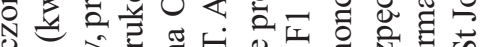

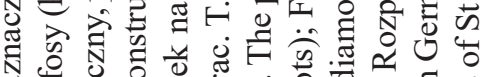

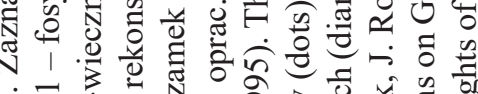
穴㞋范 ลे o

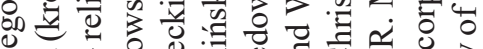

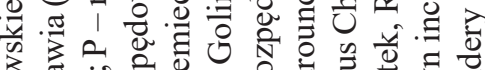

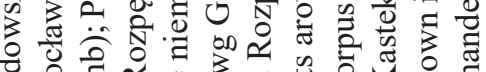

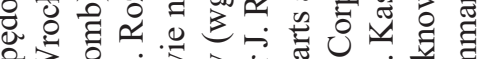

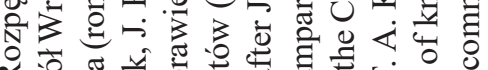

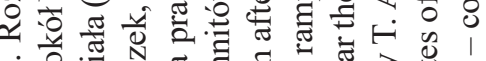

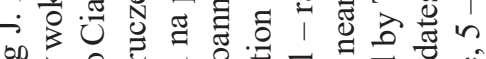

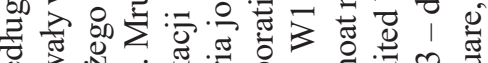

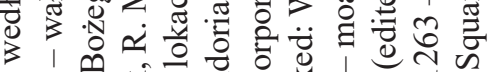

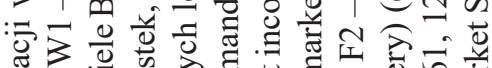

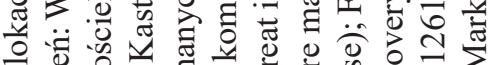
ब.

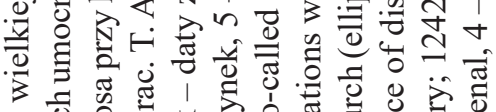

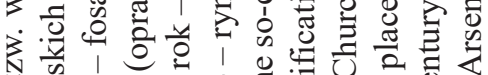

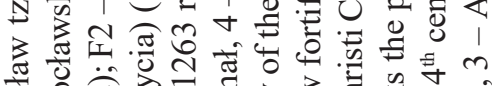

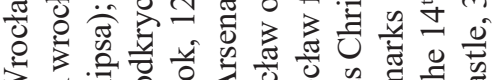

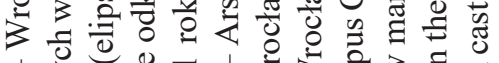

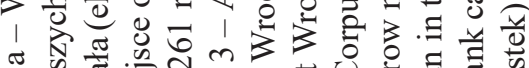

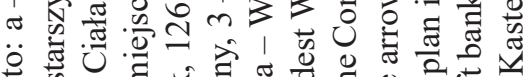

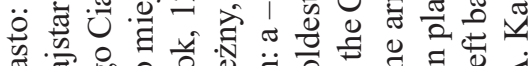

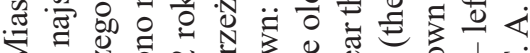

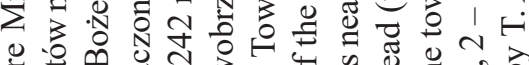

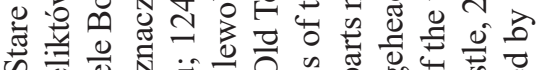

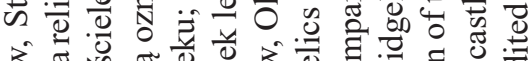
है.

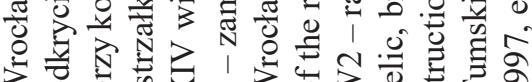

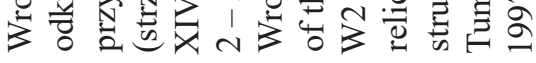

$\stackrel{\infty}{\dot{2}}$

$\dot{\infty}$ 
w latach 1226-1232; wówczas też zaczęła powstawać pierwsza lewobrzeżna rezydencja książęca w rejonie obecnego Uniwersytetu Wrocławskiego. Pamiątką z czasu powstawania pierwszego ośrodka miejskiego jest wał piaszczysto-faszynowo-ziemny odkrywany wokół tzw. wielkiej lokacji, identyfikowany głównie pod zewnętrznym, XIV-wiecznym obwodem obronnym, który został wkopany w ten wał. Również i wewnętrzny, XIII-wieczny obwód obronny w częściach północnej (nadodrzańskej) i wschodniej został posadowiony na tych obwarowaniach ziemnych (ryc. 9: a, b) ${ }^{16}$.

W granicach lewobrzeżnego ośrodka miejskiego, w obrębie wałów ziemnych wytyczono Rynek (Piekalski 2014, s. 72-78), pojawił się targ, przeniesiony z Ołbina, przeprawa została przeniesiona na zachód (w obręb zamku lewobrzeżnego), powstała murowana zabudowa mieszczańska ${ }^{17}$, a teren tego dużego ośrodka został rozparcelowany na całym obszarze w obrębie obwałowań ${ }^{18}$. Na tak zagospodarowanym obszarze pojawiała się prawdopodobnie pierwsza lewobrzeżna rezydencja książęca, którą wzniesiono w wysuniętym zakolu rzeki przy przeniesionej przeprawie przez Odrę.

Osłabienie gospodarcze, które było skutkiem najazdu tatarskiego, a także obawa przed kolejnym najazdem spowodowały, że miasto zostało ponownie lokowane w 1242 roku przez księcia Bolesława Rogatkę. Wynikiem tej lokacji była budowa pierwszego murowanego obwodu obronnego, którego relikty dochodziły do zamku lewobrzeżnego ${ }^{19}$.

${ }^{16}$ Istnienie wałów w tej części Wrocławia - przy zachowanym wschodnim odcinku i baszcie czworobocznej przy ulicy Kraińskiego - po raz pierwszy zidentyfikował J. Kaźmierczyk (1957, s. 118-120; 1965, s. 150 i nn.; 1970, s. 76). Nasypy odkrywane były w nadbrzeżnej części, w takich miejscach jak: Brama Piaskowa, tereny zamku lewobrzeżnego, czy też Arsenału (zamek lewobrzeżny II), mimo szczątkowego ich zachowania (por. przypis 7). Zaskoczeniem było odkrycie przez zespół dr. Cz. Lasoty nawarstwień wału ziemnego pod najstarszymi reliktami identyfikowanymi jako zamek lewobrzeżny II. W związku z tym, że nadal trwają tam prace można spodziewać się kolejnych odkryć wału ziemnego i reliktów zamkowych.

17 Nowe rozmierzenie rynku po lokacji przeprowadzonej w 1242 roku oraz budowa pierwszego murowanego obwodu obronnego spowodowały zniszczenia starszej zabudowy mieszczańskiej. Przykładem może być Brama Oławska I, która posadowiona została na reliktach starszej piwnicy, czy też kamienica Rynek 60, gdzie najstarsza zabudowa murowana przechodziła na sąsiednią działkę nr 59, a nowo powstały budynek po parcelacji obudował starszy obiekt (Limisiewicz, Mruczek 2010, s. $90-96,125-126$, ryc. 10,11$)$.

${ }^{18}$ Ze względu na brak XIII-wiecznych odkryć archeologicznych oraz późną zabudowę murowaną uznano, że zasiedlenie późnośredniowiecznego kwartału Słodowniczego nastąpiło dopiero w XIV wieku (Goliński 1997, s. 140-187). Wyniki przeprowadzonych w ostatnich latach badań archeologicznych na ulicy Zamkowej pozwoliły zidentyfikować rowy wiązane z wczesną parcelacją, odkryto również negatywy z niezidentyfikowanej do tej pory XIII-wiecznej konstrukcji, funkcjonującej równoczasowo z wałami piaszczysto-faszynowo-ziemnymi (Kastek, Mruczek 2016, s. 20-22, ryc. 1b, Kastek 2017 s. 46, plansza 5).

${ }^{19}$ Wspomniane relikty od wschodu łączyły się z czworoboczną wieżą od wschodu i z budynkiem pałacowym założenia zamkowego od zachodu. Obwód ten od południowej strony miasta uzyskał potrójną kurtynę murów, natomiast od zachodniej - zdwojoną. 

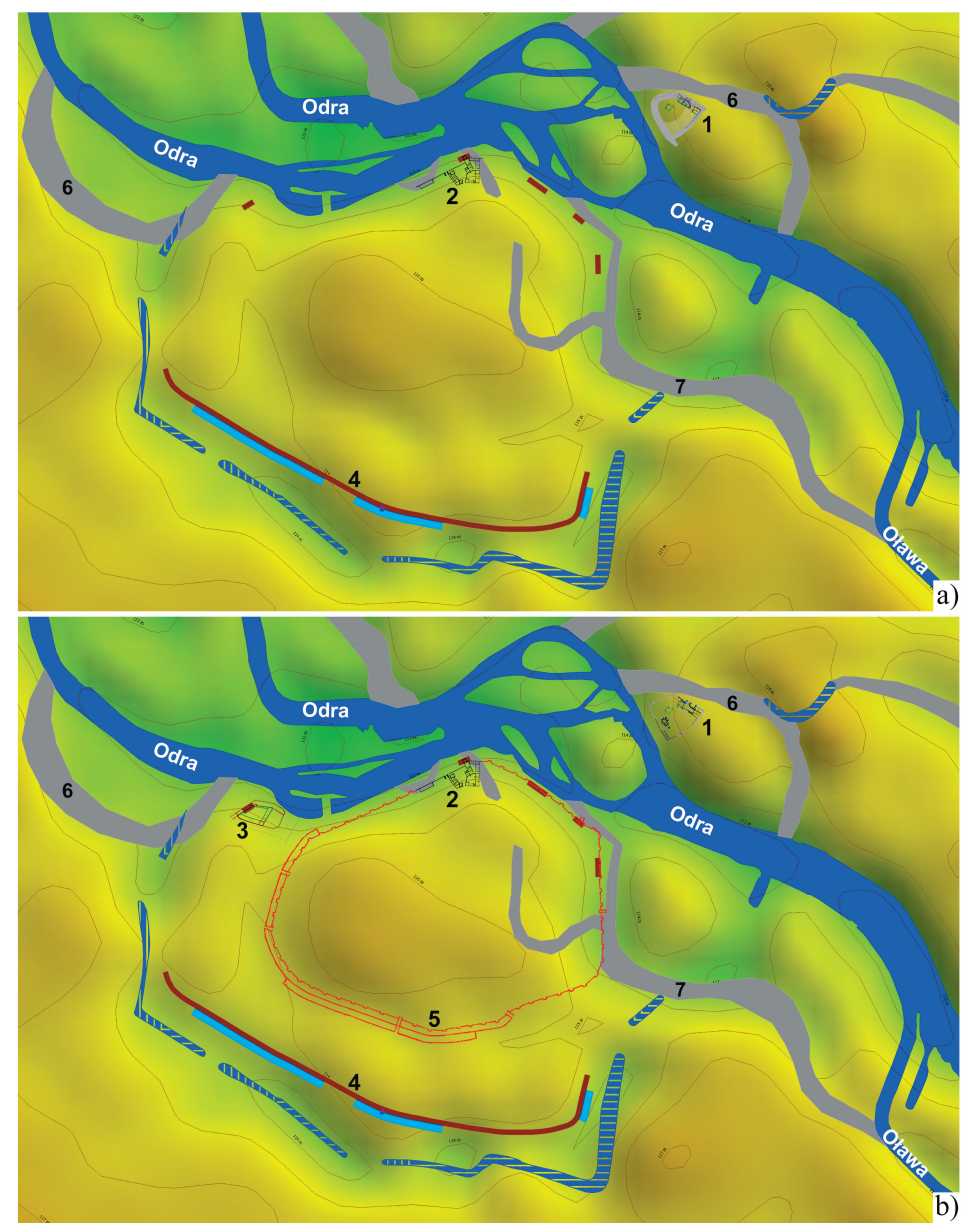

Ryc. 9. Wrocław. Stare Miasto i zamki wrocławskie na tle naturalnego poziomu próchnicznego oraz zidentyfikowanych starorzeczy Odry i Oławy: 1 -zamek na Ostrowie Tumskim; 2 - zamek lewobrzeżny; 3 - zamek lewobrzeżny II (Arsenał); 4 - obwarowania ziemne: wał piaszczysto-faszynowo-próchniczny z fosą XIII-wieczną; 5 - XIII-wieczny murowany obwód obronny; 6 - starorzecza Odry; 7 - starorzecze Oławy; a - Wrocław w 1. połowie XIII wieku; b - Wrocław w 2. połowie XIII wieku (oprac. J. Badura, T. A. Kastek)

Fig. 9. Wrocław. Old Town and Wrocław castles against the background of the natural humus level and the identified oxbow lakes of the Odra and the Olawa rivers: 1 - Ostrów Tumski castle; 2 - left bank castle; 3 - left bank castle II (Arsenal); 4 - earthen ramparts: sandy-earthen and fascine ramparts with the $13^{\text {th }}$-century moat; $5-13^{\text {th }}$-century masonry defensive perimeter; 6 - the Odra River's oxbow lake; 7 - the Oława River's oxbow lake, a-Wrocław in the first half of the $13^{\text {th }}$-century; $\mathrm{b}$ - Wrockaw in the second half of the $13^{\text {th }}$ century (edited by J. Badura, T. A. Kastek) 
W 1261 roku nastąpiła ponowna relokacja miasta wykonana przez książąt Henryka III i biskupa Salzburskiego Władysława. W jej wyniku poszerzono jego zasięg o tereny zajęte przez wspomniane wały piaszczysto-faszynowo-ziemne. Jednak obwód obronny tak rozszerzonego obszaru miejskiego zabudowano dopiero w latach 1299-1348. Powstał wtedy murowany obwód obronny, który łączył się z nieukończonym zamkiem II (Arsenał). Prawdopodobnie decyzja związana z drugą relokacją dała przyczynek pod budowę zamku na wyższym zakolu rzeki, ale w obrębie powiększonego miasta. Śmierć księcia Henryka IV, spowodowała porzucenie koncepcji budowy wielkiej rezydencji. Po przejściu Wrocławia pod władanie czeskie, w latach 1346-1378, powstała nowa, cesarska rezydencja na lewym brzegu, ale nie były to tereny zamku II, lecz rozbudowywana pierwsza rezydencja książęca.

Powstawanie zamków we Wrocławiu zdeterminowane było miejscem sprawowania władzy książęcej, jakim był gród na Ostrowie Tumskim, natomiast lewobrzeżnych powiązane było bezpośrednio z tworzeniem się na tych terenach ośrodka miejskiego. Charakterystyczne współistnienie zamek - miasto widoczne jest dla wielu ośrodków na Dolnym Śląsku, na przykład Głogowa, Namysłowa, Środy Śląskiej, Strzegomia. Ważnym czynnikiem ulokowania lewobrzeżnych siedzib książęcych było ukształtowanie nadbrzeżnych terenów Odry, na tzw. ostrogach.

Początki lewobrzeżnych zamków są nadal mało znane. Zamek lewobrzeżny I powstał prawdopodobnie jako rezydencja, której jednym z głównych zadań była obrona przeniesionej przeprawy odrzańskiej. Nietrafiona lokalizacja, związana $\mathrm{z}$ usytuowaniem na niezbyt pewnym geologiczne terenie, spowodowała, że za czasów panowania książąt piastowskich w XIII-wiecznym Wrocławiu, rezydencja ta nie rozwijała się, jak to miało miejsce na Ostrowie Tumskim. Dodatkowym czynnikiem hamującym jej rozwój były fundacyjne zamysły Henryka II i jego żony Anny, stanowiące ukłon w stronę Kościoła. Prawdopodobnie dopiero budowa drugiego z zamków lewobrzeżnych, który został umiejscowiony na wyższej terasie, miała stworzyć właściwą rezydencją książęcą lewobrzeżnego Wrocławia. Wydaje się, że śmierć księcia Henryka IV mogła być przyczyną zaniechania dalszej inwestycji w tym miejscu. Jedynie zamek na Ostrowie Tumskim był tym, który pełnił funkcje reprezentacyjne od powstania aż do zbycia wraz z terenem, na którym stał, na rzecz Kościoła. 


\section{Bibliografia}

\section{Źródła}

BUb. $\quad-\quad$ Breslauer Urkundenbuch, t. 1, red. G. Korn, Breslau 1870.

KDŚl. - Codex diplomaticus nec non epistolaris Silesiae. Kodeks dyplomatyczny

Śląska, t. 2, wyd. K. Maleczyński, A. Skowrońska, Wrocław 1959.

SUb. $\quad$ - Schlesisches Urkundenbuch, t. 1: 1 (Lieferung 971-1230), 1963;

2. (Lieferung 1217-1230), 1968; 3. (Lieferung Fälschchungen und Register), 1971, red. H. Appelt, oprac. H. Appelt, J. J. Menzel, Wien-Köln-Graz 1963-1971;

Schlesisches Urkundenbuch, t. 2 (1231-1250), oprac. W. Irgang, red. H. Appelt, J. J. Menzel, Wien-Köln-Graz 1977;

Schlesisches Urkundenbuch, t. 3 (1251-1266), oprac. W. Irgang, red. H. Appelt, J. J. Menzel, Köln-Wien 1984.

\section{Literatura}

Wykaz skrótów

ŚSA - Śląskie Sprawozdania Archeologiczne, Wrocław

DWKZ - Dolnośląski Wojewódzki Konserwator Zabytków

Atlas historyczny

2001 Atlas historyczny miast polskich, red. A. Czacharowski, t. 4: Ślask, red. M. Młynarska-Kaletynowa, z. 1, red. M. Młynarska-Kaletynowa, R. Eysymont, Wrocław.

Badura J.

2009 Powierzchnia przedlokacyjna w rejonie ulic Zamkowej i Modrzejewskiej we Wrocławiu, maszynopis w archiwum Akme - Zdzisław Wiśniewski Sp. z o.o., Wrocław.

2010 Geomorfologiczne uwarunkowania lokalizacji lewobrzeżnego osadnictwa Wroctawia, [w:] Ulice średniowiecznego Wroctawia, red. J. Piekalski, K. Wachowski, Wratislavia Antiqua 11, s. 15-45.

Badura J., Burdukiewicz J. M.

2016 Zdarzenia powodziowe $i$ ich pochodne $w$ dolinie Odry między Chatupkami a Wroctawiem $w$ świetle danych archeologicznych $i$ geologicznych, [w:] Klęski żywiolowe w postaci zdarzeń powodziowych i ich pochodnych na Ślasku od XIV do XX wieku, red. E. Kościk, B. Konopska, Warszawa, s. 63-111.

Badura J., Jary Z., Smalley I.

2013 Sources of loess material for deposits in Poland and parts of Central Europe: the lost Big River. Quaternary International, t. 296, s. 15-22. 
Badura J., Kastek T., Mruczek R., Stefanowicz M.

2010 Znowszych badań obwarowań i fortyfikacji Wrocławia, cz. 1: Pas poludniowy w rejonie obecnego Pl. Wolności, ŚSA, t. 52, 365-425.

Badura J., Przybylski B., Zuchiewicz W.

2004 Cainozoic evolution of Lower Silesia, SW Poland: a new interpretation in the light of sub-Cainozoic and sub-Quaternary topography, Acta Geodynamica et Geomaterialia, t. 1, nr 3(135), s. 7-29.

Bimler K.

1933 Die ehemalige Kaiserburg in Breslau, Braslau.

Bukowski M.

1979 Arsenat wrocławski przy Bramie Mikołajskiej, Wrocław.

Burak M.

2012 Arsenat Wrocławski. Przewodnik historyczny, Wrocław.

Chorowska M.

2014 Dylematy wokót zamku książęcego na Ostrowie Tumskim we Wroctawiu w'świetle badań archeologiczno-architektonicznych z lat 2011-2012 oraz 2014, [w:] Katedra, ratusz, dwór. Wielkie miasta a władza świecka i kościelna w kulturze średniowiecznej Europy. Materiały XXXIII Seminarium Mediewistycznego im. Alicji Karłowskiej-Kamzowej, 29 listopada-1 grudnia 2012 w Poznaniu, red. J. Kowalski, T. Ratajczak, Poznań, s. 137-163.

2017 Zamek ksiązęcy na Ostrowie Tumskim - komentarz do planszy, [w:] Atlas historyczny miast polskich, red. R. Czaja, t. 4: Śląsk, red. M. Młynarska-Kaletynowa, z. 13, cz. 1 i 2: Wrocław, red. R. Eysymontt, M. Goliński, Wrocław, s. $42-43$, plansza 6 .

Goerlitz T.

1935 Eine Mardeburger Rechtsmitteilung für Breslau vor 1241? Gleichzeitzeiting eine Untersuchung zum Magdeburg-Goldberger Rechte, Beiträge zur Geschichte der Stadt Breslau, z. 1, Breslau.

Goliński M.

1997 Socjotopografia późnośredniowiecznego Wrocławia (przestrzeń-podatnicy-rzemiosto), Acta Universitatis Wratislaviensis, nr 2010, Historia 134, Wrocław.

Grzempowski P., Badura J., Cacoń S., Przybylski B.

2009 Recent vertical movements in the Wroclaw section of the Middle Odra Fault Zone, Acta Geodynamica et Geomaterialia, t. 6, nr 3(155), s. 339-349.

Kasprzak M.

2010 Wezbrania i powodzie na rzekach Dolnego Śląska, [w:] Wyjątkowe zdarzenia przyrodnicze na Dolnym Ślasku i ich skutki, red. P. Migoń, Wrocław, s. $81-140$.

Kastek T.

2017 Obwarowania wczesnego Wroctawia-komentarz do planszy, [w:] Atlas historyczny miast polskich, red. R. Czaja, t. 4: Śląsk, red. M. Młynarska-Kaletynowa, z. 13, cz. 1 i 2: Wrocław, red. R. Eysymontt, M. Goliński, Wrocław, s. 46 , plansza 5 . 
Kastek T. A., Mruczek R.

2016 Średniowieczne obwarowania i fortyfikacje Wrocławia w świetle odkryć w rejonie Narodowego forum Muzyki, [w:] Centrum Staromiejskie we Wroctawiu, Wrocław, s. 10-36.

Kaźmierczyk J.

1957 Z badań wykopaliskowych Wrocławia w roku 1956, Archeologia Śląska, t. 1, s. 192-193.

1959a Wyniki badań wykopaliskowych na dziedzińcu uniwersyteckim we Wrocławiu, Archeologia Śląska, t. 2, s. 223-245.

1959b Sprawozdanie z badań archeologicznych Wrocławia za rok 1957, Zeszyty Naukowe Uniwersytetu Wrocławskiego, Seria A, nr 18, s. 109-128.

1965 Z badań nad kształtowaniem się wczesnośredniowiecznego ośrodka miejskiego na lewym brzegu Odry we Wrocławiu, Śląski Kwartalnik Historyczny Sobótka, R. 20, nr 2, s. 137-169.

1970 Wrocław lewobrzeżny we wczesnym średniowieczu, t. 2, Wrocław.

Kmiecik P., Szwed R.

2018 Wystrój kamieniarski opactwa na Otbinie wświetle najnowszych odkryć archeologiczno-architektonicznych na terenie bytego szpitala im. Józefa Babińskiego we Wroctawiu, [w:] Od benedyktynów i premonstratensów do salezjanów, dzieje kościoła i parafii św. Michała Archanioła na wrocławskim Otbinie, red. M. Wójcik, Wrocław-Borowianka, s. 79-86, 331-340.

w druku Drugi zamek lewobrzeżny we Wrocławiu w świetle najnowszych badań archeologiczno-architektonicznych.

Konczewski P., Lasota Cz., Piekalski J.

2007 Zamek książęcy na lewym brzegu Odry we Wrocławiu w świetle badań z lat 2005-2006, ŚSA, t. 49, s. 225-253.

2014 The Town Castle in Wrocław, [w:] Středověká Evropa v pohyblu. K poctě Jana Klápště, red. I. Boháčová, P. Sommer, Praha, s. 201-211.

Leonhard R.

1901 Die Entwickelung der Stromlage der Oder bei Breslau, [w:] Breslau. Lage, Natur und Entwickelung. Eine Festgabe dem XIII. Deutschen Geographentage, dargeboten vom Ortsausschusse, Breslau, s. 39-47.

Limisiewicz A., Mruczek R.

2010 Fara św. Marii Magdaleny na tle przemian przestrzennych Wrocławia, [w:] Śródmiejska katedra. Kościót św. Marii Magdaleny w dziejach i kulturze Wrocławia, red. B. Czechowicz, Wrocław, s. 55-136.

Limisiewicz A., Pankiewicza A., Szynkiewicz A.

2015 Obwarowania wrocławskiej wyspy tumskiej w świetle badań georadarowych, [w:] Kształtowanie sie grodu na wrocławskim Ostrowie Tumskim. Badania przy ul. św. Idziego, red. A. Limisiewicz, A. Pankiewicz, Wrocław, s. 33-54.

Małachowicz E.

1993 Wrocławski zamek książęcy i kolegiata św. Krzyża na Ostrowie, Wrocław.

1994 Ksiązęce rezydencje, fundacje i mauzolea w lewobrzeżnym Wrocławiu, Wrocław. 
Młynarska-Kaletynowa M.

1986 Wrockaw w XII-XIII wieku. Przemiany społeczne i osadnicze, Wrocław. Morelowski M.

1955 Wykopaliska na terenie lewobrzeżnego zamku Piastów we Wrocławiu, Ochrona Zabytków, t. 1, s. 10-16.

Mruczek R., Nowakowski D., Piekalski J., Stefanowicz M., Wachowski K.

2003 Sprawozdanie z ratowniczych badań archeologicznych przeprowadzonych na dziedzińcu Uniwersytetu w 2002-2003 r., maszynopis w archiwum DWKZ, Wrocław.

Mruczek R., Nowakowski D., Stefanowicz M.

2005 Zamek lewobrzeżny we Wrocławiu w świetle nowszych badań, ŚSA, t. 47, s. $175-191$.

Mruczek R., Stefanowicz M.

2000 Badania archeologiczno-architektoniczne w rejonie zamku lewobrzeżnego we Wrocławiu w 1999 roku, ŚSA, t. 42, s. 237-251.

Pankiewicz A.

2015 Stan badań nad konstrukcjami obronnymi wrocławskiego Ostrowa Tumskiego, [w:] Kształtowanie sie grodu na wrocławskim Ostrowie Tumskim. Badania przy ul. św. Idziego, red. A. Limisiewicz, A. Pankiewicz, Wrocław, s. 13-31.

Piekalski J.

2014 Praga, Wrocław, Kraków. Przestrzeń publiczna i prywatna w czasach średniowiecznego przełomu, Wrocław.

Piszczałowski W.

1982 Wrocław. Arsenat Wrocławski, Informator Archeologiczny. Badania rok 1980, s. 277-278.

Piwko R., Romanow J.

1994 Południowy odcinek fosy zamkowej. Badania archeologiczne-czerwiec 1994 r. V etap badań, maszynopis w archiwum DWKZ, Wrocław.

1996 Średniowieczna zabudowa wschodniej części ul. Cieszyńskiego we Wrocławiu. Wyniki badań archeologiczno-architektonicznych przeprowadzonych w 1996 r., maszynopis w archiwum DWKZ, Wrocław.

Romanow J.

1979 Arsenał Wrocławski, skrzydło południowe. Wyniki badań archeologicznych, maszynopis w archiwum DWKZ, Wrocław.

1992 Arsenał Wrocławski. Wyniki badań archeologiczno-architektonicznych. III etap badań, maszynopis w archiwum DWKZ, Wrocław.

1994 Arsenał Wrocławski. Badania archeologiczno-architektoniczne w roku 1993/94. IV sezon badań, maszynopis w archiwum DWKZ, Wrocław.

2001 Chronologia Bramy Piaskowej w świetle wyników badań wykopaliskowych w roku 2000, Silesia Antiqua, t. 42, s. 133-147.

Romanow J., Romanow M.

2010 Szpital Ducha Świętego we Wrocławiu w świetle badań archeologicznych, Wratislavia Antiqua 12, s. 171-180. 
Rozpędowski J.

1995 Wrocław pierwszej lokacji, [w:] Architektura Wrocławia, t. 2: Urbanistyka, red. J. Rozpędowski, Wrocław, s. 41-52.

2011 Breslau zur Zeit der ersten Lokation, [w:] Rechtsstadtgründungen im mittelalterlichen Polen, red. E. Mühle, Köln-Weimar-Wien, s. 127-138.

Traczyk A.

2005 Geomorfologia Starego Miasta we Wrocławiu w rejonie placu Nowy Targ, [w:] Wschodnia strefa Starego Miasta we Wroctawiu w XII-XIV wieku, red. C. Buśko, Wrocław, s. 9-17.

Wroctaw

1999

Wrocław na planach XVI-XX wiek, red. H. Okólska, Wrocław.

Żurek A.

1996 Wrocławska kaplica św. Marcina w średniowieczu, Wrocław.

\section{TOPOGRAPHICAL CONDITIONS OF THE LOCATION OF WROCEAW CASTLES}

Keywords: Wrocław, Middle Ages, Odra River, topography of the pre-incorporation town, Piast castles.

Summary

The analysis of geological data, including excavations at archaeological sites, as well as cartographic materials and written sources, suggests that the origins of Wrocław islands are closely related to both frequent changes in the Odra River meandering channel as well as intentional human activity. The shape of the riverine network in this area suggests that in the Old Town section the Odra River flows in a tectonically decreasing place. Such a picture results only from the difficulties posed by the reconstruction of the old courses of meandering channels, often filled with anthropogenic layers up to 4-5 $\mathrm{m}$ thick. The analysis of old maps and the time of the creation of mills and bridges established in their vicinity indicates that the majority of the Wrocław islands were created both during the flood avulsions of the Odra River and as a result of artificial ditches through meander spurs. Piasek Island (Sand Island) lost its connection with the left bank town as a result of flood avulsion. The Odra River cut the base of the wide meander spur, partly using the mouth section of the Oława River. The name of this newly created channel - Odrzyca, reflects the rapid character of this Odra River arm and may contain a reference to its creation after one of medieval floods. It seems that these changes took place between the $11^{\text {th }}$ and the beginning of the $12^{\text {th }}$ century, hence they are partly documented by the creation of new mills and bridges on the islands. Ostrów Tumski (Cathedral Island), and the islands: Bielarska, Młyńska and Słodowa were created as a result of intentional digging of ditches.

In such a changing landscape, Wrocław castles were formed. The first of them was built during the rule of Bolesław the Tall. It was an eighteen-sided structure with a diameter of about $25 \mathrm{~m}$, built into the north-eastern part of the stronghold's ramparts. In subsequent phases, the reconstructions and extensions of the castle complex followed. It received an apron wall located $1 \mathrm{~m}$ from the tower (phase II). After moving the ramparts 
to the east, a building with hypocaust furnaces was built. In the following year a buttressed tower (donjon) was erected to the east of the eighteen-sided building. This tower and partly dismantled eighteen-sided building were merged into a monumental palace (phase V). Around the mid- $13^{\text {th }}$ century, at culminations of the stronghold's ramparts, a defensive masonry perimeter was built with quadrangular towers on the south and east side, while on the north side a buttressed one. In the last major phase of the reconstruction, an eight-sided construction with a diagonal of $17.6 \mathrm{~m}$ was erected in place of the former eighteen-sided building (Chorowska 2017).

The first left bank ducal residence was probably established when the river crossing was moved to the west of the later Sand Gate (1230-1231). This happened as a result of the conflict of Henry I the Bearded with regular canons from Piasek and Norbertines from Ołbin. Kurt Bimler saw this castle as a two-segment structure. It consisted of an upper castle, containing a cylindrical bergfried tower (in the northern part), a palace building, a kitchen, servants' rooms, a well and master's rooms, enclosed in a triangle. The second segment - a secondary one, in the western part, contained a light tower in the northern part and a courtyard that had an economic function. Bergfried was supposed to be located at the joint of both segments. According to K. Bimler, the complex functioned in the $12^{\text {th }}-13^{\text {th }}$ century. During the construction of the Chemistry Building (1895-1897) foundations of a cylindrical tower with four meters thick walls were discovered, which did not exist anymore in 1350 (Bimler 1933; Mruczek et al. 2005). During the excavations in 1999-2006, the remains of sandy embankments were identified, in which the $13^{\text {th }}$-century defensive wall was dug.

The second of the left bank castles was built in the north-western corner of the Old Town. The complex, measuring approximately $132 \times 70 \mathrm{~m}$, was identified by Jerzy Romanow (1979) as an unfinished mayor's castle built during the times of Henry IV, which was separated from the town by a moat (Romanow 1979). On the unfinished foundations of the castle was erected in the years 1459-1741 the Municipal Arsenal. The research revealed that the foundations of the western part of the castle were located on a sandy embankment identified with the $13^{\text {th }}$-century town walls perimeter.

The creation of left bank castles was directly associated with creation of the urban centre in Wrocław. With the oldest urban settlement of left bank Wrocław is associated a sandy-earthen and fascine ramparts discovered around the so-called great incorporation (Rozpędowski 1995). Its creation can be associated with the development of left bank areas prior to their incorporation on German law in 1242 under Bolesław Rogatka as well as in 1261 in times of Duke Henry III and his brother, Bishop Władysław. Around the mid$-13^{\text {th }}$ century the construction of the first masonry defensive perimeter began, which was associated with the first left bank ducal residence. The construction of the next residence occurred after the town incorporation in 1261 during the rule of Henry IV. 
